Preprints are preliminary reports that have not undergone peer review.

They should not be considered conclusive, used to inform clinical practice,

or referenced by the media as validated information.

\title{
Spatio-temporal dynamics and evolution of land use transition and landscape patterns in response to ecological protection project in Guizhou Province, China
}

\author{
Quan Wang ( $\nabla$ excellent_wangquan@126.com ) \\ Wuhan University https://orcid.org/0000-0002-5354-0268 \\ Xuepiao Bai \\ Beijing Normal University
}

Research Article

Keywords: Land use transition, Landscape pattern, Long-term sequence, Mountainous areas of Karst, Guizhou Province

Posted Date: March 7th, 2022

DOI: https://doi.org/10.21203/rs.3.rs-1364652/v1

License: @ (i) This work is licensed under a Creative Commons Attribution 4.0 International License. Read Full License 


\section{Abstract}

Restoration of degraded ecological environment is a global core issue, particularly in the ecologically fragile mountainous areas where excessive loss of natural vegetation has occurred, and the rational land use and ecological protection need high attention from academia. This study explored the dynamics of land use transition and landscape pattern by using large-scale remote sensing, geological information model, and landscape pattern method, to understand internal mechanism process for spatial difference at the prefecture-level city level. The results showed that the area of forestland, grassland, and urban and rural construction land showed an increasing trend during 1990-2015. The land use transition trend was mainly based on the mutual conversion between grassland, urban and rural construction land, cultivated land, and forestland, and were widely distributed in Guiyang, Qiannan, Zunyi, and Tongren. During 1990-2000 and 2005-2010, the largest changes of land use rising were forestland and grassland; during 20002005 and 2010-2015, the areas of land use shrinkage changes were cultivated land and grass land, as well as overall land use transition was becoming more intensive and efficient. Under the interaction of natural environment and human activities, severe land use transition led to the increasing trend of landscape pattern from low density to high fragmentation, patch richness, diversity, and irregular patch shape, enhancing regional spatial heterogeneity. Finally, we put forward realistic policy recommendations to provide a basis for the development of land space planning, regional ecological protection, and sustainable development in mountainous areas.

\section{Introduction}

Land use is a complex dynamic process of natural and human activities (Debnath et al. 2020). With the acceleration of economic development, the regional land use intensity has undergone significant changes, and the pressure on land use resources has become increasingly prominent (Tellman et al. 2021; Deng et al. 2021). However, local land use has shown the characteristics of diversification, refinement, and complexity. Regional land resources have obvious landscape heterogeneity in terms of quantity, quality, structure, location, which affects the efficiency of land resource utilization and management, and the construction of new urbanization in China (Ullah et al. 2020). At present, the study of land use transition in academia is a new way to comprehensively explore land use/land cover changes (LULCCs), which is a transition process of regional land use forms corresponding to the stage of socioeconomic development (Lambin and Meyfroidt 2010; Qu et al. 2019). The land use transition pattern initially are the changes in the quantitative structure of the main land use types in a certain period of time at a certain area, and then it is expanded into a drastic change in the spatial functional structure of a certain land use type (Gibbes et al. 2017). With the deepening of research in China and other countries, the long-term land use transition has been further defined as dominant form and recessive forms (Tian et al. 2020; Zhu et al. 2018; Long et al. 2020, 2012). The dominant form is the constituent structure of regional land use type in a specific period, while the recessive form is dependent on the dominant form and can be obtained by quantitative analysis (Long and Li 2012).

Existing literature studies have found that land use transition includes the transformation of land use function and potential benefit value, both of which drives the change of regional ecological environment (Drummond and Loveland 2010; Chen and Han 2015; Ouedraogo et al. 2016). Due to the influences of long-term social, economic, and natural environmental factors in different regions, the dominant function of land use transition is spatially and temporally different. The spatial evolution of land use transition is manifested as agglomeration and dispersion effect of land use function (Zhu et al. 2014). The number of land use structure increases or decreases directly lead to the obvious trend of weakening or strengthening some land functions (Wang et al. 2014; Kamwi and Mbidzo 2020). In China's complex mountainous areas, the transition of rural land use in mountainous areas has been accompanied by a reduction in labor input and a decline in intensification (Cheng et a. 2020; Liang et al. 2020). These processes have led to the evolution of ecological forest land from shrinking to expanding and the trend of cultivated land from expanding to shrinking, leading to a trend of restoration of rural land ecological functions (Wang et al. 2014; Achieng et al. 2020). The land use transition around cities has shown a trend of diversification of functions and weakening of ecological functions. Up to now, land use transition mainly focus on the structure and quantity of land use types, quantitative identification of land use function, spatiotemporal characteristics of land use transition, driving mechanism, and ecological environment response (Turnbull and Wainwright 2019; Meiyappan and Jain 2012; Bessah et al. 2019). In addition, some scholars believe that land use transition is a macro process of long-term land use evolution, and its morphological function evaluation is combined with the characteristics of regional land use types (Zhang et al. 2007; Yang et al. 2021). The sustainability of land resource use is based on the dynamic changes of the regional characteristics that conform to the transition of land use types under the socioeconomic transformation in a certain period of time (Gomes et al. 2020). However, the understanding and practical guidance of land use transition in Karst area under the transition of land use function form should be further improved. To strengthen the pertinence of practice guiding land use management in these complex Karst areas, it is necessary to analyze the coordination relationship of landscape ecological pattern on the basis of identifying regional land use functions.

Landscape pattern is the morphological and structural characteristics of complex landscape elements in a certain region in time and space (Buyantuyev and Wu 2007; Yeh and Huang 2009). It is the final result of various natural and man-made factors acting on different spatial and temporal scales, and is manifested as the process of landscape spatial heterogeneity (Sklenicka and Pixova 2004). Quantitative analysis of landscape pattern is the basis of the interrelationship between global and local pattern and processes at different scale, it is also an effective indicator to characterize the complexity of regional change (Garrigues et al. 2008). Land use transition and landscape pattern change are important indicators of system coordination between socioeconomic system and natural ecosystem. With the advancement of urbanization and industrialization, urban and rural landscapes show a significant feature of low density to high fragmentation, and the natural landscape with a single, integral, and discontinuous structure that tends to be complex, heterogeneous, and continuous mixed patches (Morelli et al. 2013; Qiu et al. 2014). Due to the drastic conversion between land use types, the continuous expansion of urban construction scale, the landscape pattern of different regions has been increasingly disturbed and its evolution pattern will become more complicated. In the fragile areas of ecological environment, the problem of deterioration of ecological environment is more prominent 
(Costantini et al. 2012). In Karst complex terrain and geomorphology areas, both urban and rural landscape systems are affected by the interaction of natural and human activities, especially in urban areas, human activities are an important driving factor for the formation and evolution of landscape diversity (Deng et al. 2018; Zhou et al. 2019). To explore the ecological environment problems caused by regional land use transition, it is of great significance to discuss the changes of landscape pattern and its driving forces in the process of industrialization and urbanization of Karst complex landform.

Most scholars mainly use the quantitative method of landscape pattern index with the geographical remote sensing (RS) and geographic information system (GIS) spatial technology to explore the landscape pattern and evolution characteristics of plain and mountainous transition regions (Wang et al. 2021; Turner and Pham 2015; Yuan and Zhang 2021), which mainly includes landscape dynamic model and landscape pattern index method (Corry 2005; Kamwi et al. 2015). Remote sensing images of different research areas were collected for correction, interpretation, and processing, the thematic maps of different landscape utilization types were obtained using GIS, and using relevant technical model to explore and monitor the dynamic change process of landscape pattern (Kelarestaghi and Jeloudar 2011). To date, landscape pattern in China have mainly focused on plains and transitional mountainous areas severely affected by human beings, while there are few research perspectives on landscape ecological processes of land use in Karst areas with complex topography and geomorphology in Southwest China. Guizhou Province is located in the Karst region of southwest China with numerous complex and dangerous topography where geological disasters and rocky desertification are prominent, and the ecological environment is extremely fragile (Fig. 1). Land use pattern is deeply influenced by topography and geomorphic conditions (Dai et al. 2017). In this area, the Karst landform is typical, the surface is rugged and broken, soil erosion is serious, and the contradiction between man-land is prominent (Zheng et al. 2019; Yang et al. 2013).

Guizhou Province has been regarded as a national key ecological governance area, and the local government has focused on implementing the stony desertification control project and the policy of returning cultivated land to forest (Huang et al. 2018). In a short period of time, rapid population growth and major infrastructure construction makes the urban built-up area continue to expand, resulting in the rapid change of land use pattern, which also leads to the shortage of land resources and the deterioration of ecological environment among many aspects. Therefore, exploring the response of land use transition process to regional landscape pattern in the process of rapid urbanization from the academic and national levels are of great significance. In this article, our main special goals were: (i) to make full use of RS, GIS spatial technology, and landscape index method to monitor the dynamics of land use transition of Guizhou Province in typical Karst area, southwest China in the past 25 years; (ii) to analyze the spatial-temporal characteristics of land use transition and landscape pattern evolution under the grain for green project; (iii) to quantitatively discuss the driving factors and internal relationship of land use transition and landscape pattern combined with multivariate socioeconomic data; (iv) to put forward relevant policy suggestions on rational land use and landscape pattern planning in mountainous area. Through the practical research of this study can help to provide scientific reference and theoretical support for further land use management and landscape ecological planning in other similar areas.

\section{Materials}

\subsection{Study area}

Guizhou Province in southwest China is abbreviated as "Qian" and "Gui", covering an area of 176,202 km², geographic location is $24^{\circ} 37^{\prime} \sim 29^{\circ} 13^{\prime}$ N, $103^{\circ} 36^{\prime} \sim 109^{\circ} 35^{\prime} \mathrm{E}$, bordering Sichuan Province and Chongqing in the north, Hunan Province in the east, Guangxi Province in the south, and Yunnan Province in the west (Fig. 2). The topography is high in the west and low in the east, tilting from the middle to the north, east and south. Guizhou is China's first national-level comprehensive experimental zone for big data, a world-renowned mountain tourism destination and a major Province for mountain tourism, and a national ecological civilization experimental zone. The landform includes four basic types, i.e., plateau, mountain, hill, and basin, $92.51 \%$ of the area is mountain and hill. Guizhou is a subtropical monsoon climate and straddles the Yangtze River and the Pearl River, it is characterized by typical development of Karst landforms. By 2021, Guizhou had 6 prefecture-level cities and 3 autonomous prefectures, with 38.5623 million permanent residents, China's GDP reached 1.68 trillion yuan, of this, the added value of the primary industry was 228.056 billion yuan, the secondary industry was 605.835 billion yuan, and the tertiary industry was 843.07 billion yuan.

\subsection{Data acquisition}

Research data mainly include land use data for 1990, 1995, 2000, 2005, 2010, and 2015 that were generated by visual interpretation of Landsat TM images in ArcGIS 10.2 by data Center for Resources and Environmental Sciences, Chinese Academy of Sciences (http://www.resdc.cn). The analytical accuracy of land use data for six periods was $30 \mathrm{~m}$. By checking and modifying the topology of the land use vector layer in each phase, these data sets were divided into six first-level types, including cultivated land (dry land and paddy land), forest land (forest land, shrub land, sparse forest land, and other forest land), grassland (high coverage grassland, medium coverage grassland, and low coverage grassland), water areas (ditches, rivers, reservoirs and lakes, etc.), urban and rural industrial and mining land (urban land, rural residential land and other construction land), unused land (abandoned land, exposed rock, sandy land and saline land) based on China's land use classification system (GB/T 21010 - 2017). In this study, Guizhou Province has a large scale, so we combined the primary and secondary land use types into 8 categories for detailed analysis (Fig. 3). In particular, the accuracy of the first-level land use data interpreted by the Chinese Academy of Sciences Data Center was over $93.56 \%$, and the second-level land use classification data was over $90.89 \%$. The details and precision of the relevant land use data in this paper can be supported by reference to the published literature (Liu et al. $2002,2010,2014$, and 2018). 
Many potential factors affecting LULC changes were selected based on literature review and actual situation of the research area (Table 1). In the long period of LULC dynamics, a large number of existing literatures show that natural factors, socioeconomic factors and neighborhood factors can significantly influence land use change (Feng and Tong 2019; Abbas et al. 2021). Among them, natural factors include terrain factors and environmental condition factors. It is generally believed that elevation, slope, terrain relief and slope aspect are potentially important driving factors affecting LULC changes (Sahoo et al. 2018; Müller et al. 2010). In the process of real social development, there are a large number of neighborhood factors such as distance to a particular urban land type (Wang et al. 2020), distance to major roads i.e., distance to the highway, the national road, the railways, and county road (Poelmans and Van Rompaey 2009), distances to urban and county centers (Sunde et al. 2014), and distance to the river (Zhang and Xia 2021), as well as socioeconomic factors, for instance, the spatial distribution of GDP and population are also important potential factors driving land use transition (Zhang et al. 2020). Each spatial factor of Guizhou Province is shown in Fig. 4.

Table 1

List and meaning of each driving factor.

\begin{tabular}{|c|c|c|c|c|c|c|}
\hline Data type & Code & Resolution/m & Year & $\begin{array}{l}\text { File } \\
\text { type }\end{array}$ & $\begin{array}{l}\text { Meaning of the spatial } \\
\text { variables }\end{array}$ & Data sources \\
\hline \multirow[t]{4}{*}{ Natural factors } & Elevation & 30 & - & GRID & The elevation of the terrain & http://www.gscloud.cn/ \\
\hline & Slope & 30 & - & GRID & The slope of the terrain & http://www.gscloud.cn/ \\
\hline & Aspect & 30 & - & GRID & The aspect of the terrain & http:// www.resdc.cn \\
\hline & $\begin{array}{l}\text { Topographic } \\
\text { relief }\end{array}$ & 30 & - & GRID & $\begin{array}{l}\text { Distribution of topographic } \\
\text { relief }\end{array}$ & http:// www.resdc.cn \\
\hline \multirow[t]{2}{*}{$\begin{array}{l}\text { Socioeconomic } \\
\text { factors }\end{array}$} & Population & 30 & \multirow[t]{2}{*}{$\begin{array}{l}1995,2005,2010, \\
\text { and } 2015\end{array}$} & GRID & $\begin{array}{l}\text { Distribution of spatialized } \\
\text { population }\end{array}$ & http:// www.resdc.cn \\
\hline & GDP & 30 & & GRID & $\begin{array}{l}\text { Distribution of spatialized } \\
\text { GDP }\end{array}$ & http:// www.resdc.cn \\
\hline \multirow{7}{*}{$\begin{array}{l}\text { Neighborhood } \\
\text { factors }\end{array}$} & Dis5WA & 30 & 2010 & Shpfile & Distance to the water area & http:// www.resdc.cn \\
\hline & Dis5HW & 30 & 2010 & Shpfile & Distance to the highway & openstreetmap.org \\
\hline & Dis5NR & 30 & 2010 & Shpfile & Distance to the national road & openstreetmap.org \\
\hline & Dis5RW & 30 & 2010 & Shpfile & Distance to the railways & openstreetmap.org \\
\hline & Dis5CR & 30 & 2010 & Shpfile & Distance to the county road & openstreetmap.org \\
\hline & Dis5CC & 30 & 2010 & Shpfile & $\begin{array}{l}\text { Distance to the county } \\
\text { centers }\end{array}$ & map.baidu.com \\
\hline & Dis5UL & 30 & 2015 & Shpfile & Distance to the urban land & http:// www.resdc.cn \\
\hline
\end{tabular}

\section{Methodology}

\subsection{Comprehensive land use dynamic degree}

The comprehensive land use dynamic degree (CLUDD) is the overall change of the land use type in the study area during the study period, which can reflect the intensity of the regional comprehensive land use change, and can also be used for the land use change rate between the local and the whole area, and between the local and local areas. (Bessah et al. 2019). Land use change rate and comprehensive dynamic change intensity (Huang et al. 2018) were analyzed by dividing the period into five period nodes. The calculation equation is as follows:

$$
K=\sum_{i=1}^{n}\left(\Delta S_{i, j} / S_{i}\right) \times T^{-1} \times 100 \%
$$

where $K$ is the CLUDD of the study area in the period $T$, and the larger the value is, the more severe the regional land use change is. $\Delta S_{i, j}$ is the total area of class $i$ land use type converted to other land use types from the beginning of the study period to the end of the study period. $S_{i}$ is the total area of category $i$ land at the beginning of the study period. $T$ is the length of monitoring period, when $T$ is set as year, $K$ is the annual change rate of land use in the study area.

\subsection{Spatial visualization method}

The study area is provincial scale has large study area and long period interval. To more clearly observe the spatial differences of land use transition and landscape pattern in Guizhou Province, each indicator selected in this study are used for dynamic analysis of spatial internal differences by grid division method. According to the situation of the research area, the size of the discriminant unit was set as $3000 \mathrm{~m} \times 3000 \mathrm{~m}$, and the research area was divided into 45,191 spatial units. 


\subsection{Geo-science information method}

We built the land use data of different periods into the land use transition map, and the newly generated map code was processed by using the map algebraic superposition operation of the two periods of land use type map unit coding. When land use type $\leq 10$ categories, its expression can be synthesized as: $Q=$ period $A \times 100+$ period $B, Q$ is the newly generated map code, period $A$ and period $B$ represents the unit codes of land use atlas in the early and late stages of the study, respectively. Thus, we can obtain the land use transition map of Guizhou Province during 1990-1995, 1995-2000, 2000-2005, 2005-2010, and 2010-2015.

\subsection{Land use transition trend}

The process of land use transition under the influence of social economy includes two dynamic changes, including transfer "into" and transfer "out". Among them, the transfer "into" is the process of transforming other land use types into local land use types, while transfer "out" is the process of transforming local land use types into other land use types. Using the ArcGIS10.2 platform to overlay the land use data of the two research periods, the newly added area and the shrinking area of a certain land category can be obtained again, that is, it is defined as an uptrend graph and a downtrend graph.

\subsection{Landscape pattern characterization index}

Landscape pattern is a comprehensive spatial feature with highly complex elements among regions, its theories and methods are universal in geography and landscape ecology (Antrop 2000, Shen et al. 2019). Each landscape pattern index highly concentrates the landscape characteristic information of a specific region, and can quantitatively reflect the spatial structure composition, spatial morphology, and dynamic evolution characteristics through their single and combined operations (Chen et al. 2016, Frazier 2019). To fully analyze the spatial characteristics of landscape pattern fragmentation and diversity of Guizhou Province in the Karst area for 1990-2015. We earnestly selected the patch density (PD), number of patches (NP), landscape shape index (LSI), largest patch index (LPI), patch richness density (PRD), contagion (CONTAG), and Shannon's diversity index (SHDI) to characterize the diversity and spatial heterogeneity of landscape pattern (De Pablo et al. 2012). Existing literature shows that these indexes can better reflect the characteristics of landscape pattern (Long et al., 2010, Ren et al., 2018), and the ecological significance and relevant algorithms of each index are detailed in the references (Table 2).

Table 2 Index and their meaning of landscape pattern.

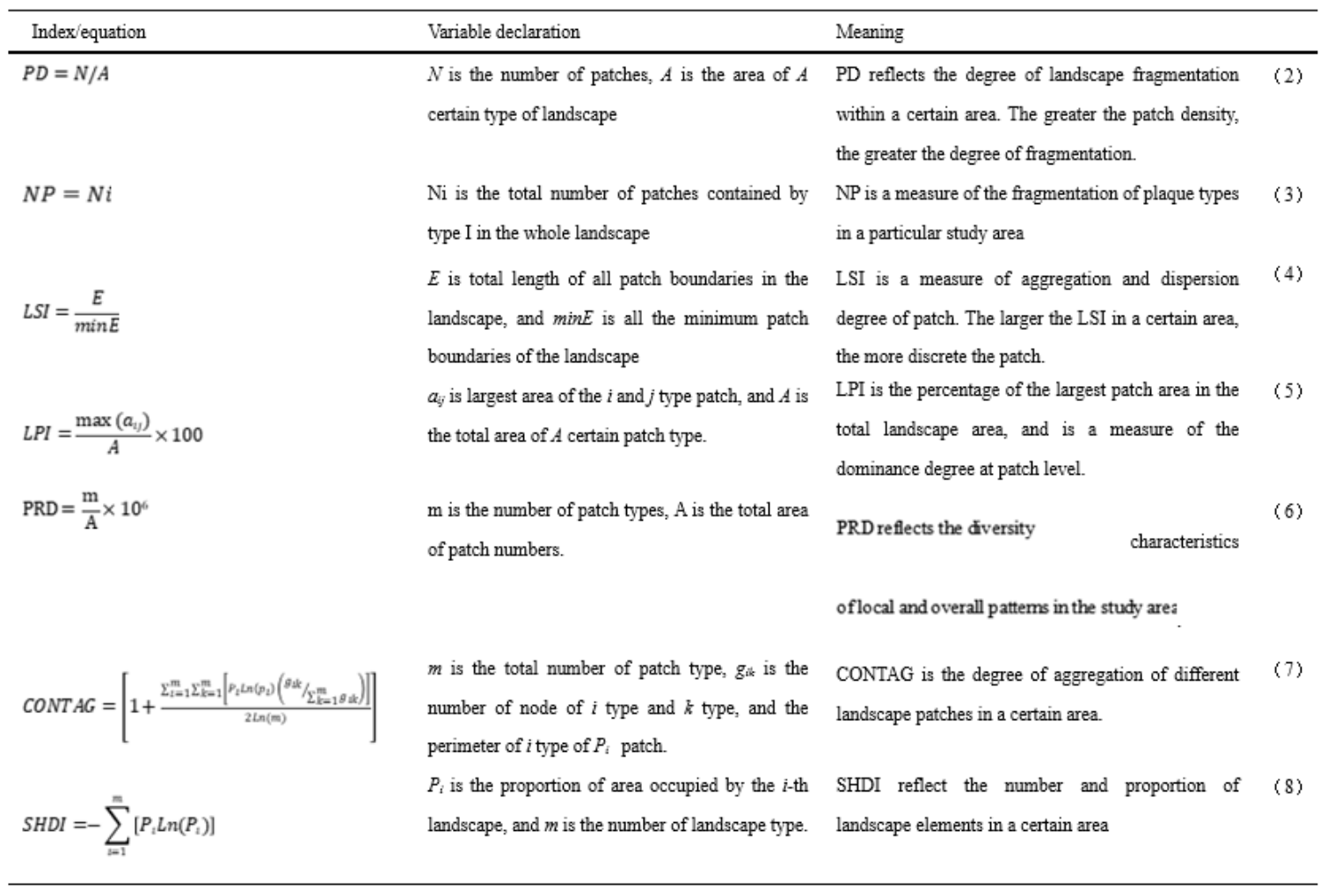

\subsection{Modified multiple logistic regression (MMLR) model}

MMLR model can well screen out the occurrence probability and intrinsic relationship of different types of factors to events at different times, and generate regression coefficients of significant factors, which can directly represent the contribution intensity of spatial factors to land use change (Overmars et al. 2003). Therefore, the MMLR model was used in this study to analyze the influencing mechanism between eight types of land use and 
each spatial factor in Guizhou Province for 1990-2015. After multicollinearity test, the variance inflation coefficient VIF was all less than 5, indicating that there was no multicollinearity between each factor, which could be analyzed in detail by the MMLR model. The mathematical equation is as follows:

$$
P k=\left[\frac{p(y=k \mid x)}{p(y=0 \mid x)}\right]=\beta_{0 k}+\beta_{1 k} x_{1}+\beta_{2 k} x_{2}+\cdots \beta_{p k} x_{p}
$$

where $y$ is dependent variable, $x$ is independent variable, there are $m$ dependent variables and $y=0$ as the reference group, then $k=0,1,2, m-1$. $P(y=k x)$ is the conditional probability of $y, \beta$ is the coefficient of the logistic regression equation, which indicates the correlation degree between independent variables and dependent variables.

\section{Results}

\subsection{Characteristics of land use transition}

The area of cultivated land in Guizhou Province decreased by $838.91 \mathrm{~km}^{2}$ for $1990-2015$, with an average annual change rate of $0.35 \%$ (Table 3 ). During 1990-1995, the area of forestland increased to $1326.84 \mathrm{~km}^{2}$, with a change rate of $0.28 \%$. During $2000-2005$, the area of forestland increased the most, with an increase of $1360.27 \mathrm{~km}^{2}(0.29 \%)$. During $2005-2010$, the change rate of grassland was $0.56 \%$, and its area decreased to $852.73 \mathrm{~km}{ }^{2}$. During 2010-2015, the change rate of grassland area was the lowest (0.13\%), but the change trend of unused land area was opposite to that of grassland. Water area, urban land, rural residential land, and other construction land showed an increasing trend from 1990 to 2015 . Among them, the area changes of water category from 2005 to 2010 reached $238.77 \mathrm{~km}^{2}$, and the change rate was $11.77 \%$. For $2010-2015$, the areas change of urban land, rural residential land, and other construction land reached $290.04,45.24$, and $746.11 \mathrm{~km}^{2}$, respectively, with the change rate of $16.63,3.40$, and $65.33 \%$, respectively. The change trend of cultivated land area was similar to that of grassland, with a small increase at first and a significant decrease later. In the previous period, the industrialization development of Guizhou Province was very backward due to the local natural condition, the local government began to implement ecological engineering management. At the same time, the policy of returning cultivated land to grassland began to take effect, and the reduced cultivated land was mainly converted into urban land, rural construction land, and grassland.

Table 3

Change rates of land use transition in Guizhou Province.

\begin{tabular}{|c|c|c|c|c|c|c|c|c|c|c|}
\hline \multirow{2}{*}{$\begin{array}{l}\text { land use } \\
\text { type }\end{array}$} & \multicolumn{2}{|l|}{ 1990-1995 } & \multicolumn{2}{|l|}{ 1995-2000 } & \multicolumn{2}{|l|}{$2000-2005$} & \multicolumn{2}{|l|}{$2005-2010$} & \multicolumn{2}{|l|}{$2010-2015$} \\
\hline & $\begin{array}{l}\text { Area } \\
\text { change/ } \mathrm{km}^{2}\end{array}$ & $\begin{array}{l}\text { Change } \\
\text { rate/\% }\end{array}$ & $\begin{array}{l}\text { Area } \\
\text { change/ } \mathrm{km}^{2}\end{array}$ & $\begin{array}{l}\text { Change } \\
\text { rate/\% }\end{array}$ & $\begin{array}{l}\text { Area } \\
\text { change/ } \mathrm{km}^{2}\end{array}$ & $\begin{array}{l}\text { Change } \\
\text { rate/\% }\end{array}$ & $\begin{array}{l}\text { Area } \\
\text { change/ } \mathrm{km}^{2}\end{array}$ & $\begin{array}{l}\text { Change } \\
\text { rate/\% }\end{array}$ & $\begin{array}{l}\text { Area } \\
\text { change/ } \mathrm{km}^{2}\end{array}$ & $\begin{array}{l}\text { Change } \\
\text { rate/\% }\end{array}$ \\
\hline $\begin{array}{l}\text { Cultivated } \\
\text { land }\end{array}$ & -1098.13 & -0.44 & 1220.90 & 0.50 & 48.52 & 0.02 & -307.82 & -0.12 & -702.38 & -0.28 \\
\hline Forest land & 1326.84 & 0.28 & -1816.43 & -0.38 & 1360.27 & 0.29 & 704.47 & 0.15 & -267.61 & -0.06 \\
\hline Grassland & -239.96 & -0.15 & 541.80 & 0.35 & -1424.64 & -0.89 & -852.73 & -0.56 & -199.65 & -0.13 \\
\hline Water area & -1.87 & -0.10 & 17.92 & 0.93 & 4.30 & 0.21 & 238.77 & 11.77 & 87.91 & 2.73 \\
\hline Urban land & -0.38 & -0.03 & 30.41 & 2.75 & 11.35 & 0.90 & 85.80 & 6.52 & 290.04 & 16.63 \\
\hline $\begin{array}{l}\text { Rural } \\
\text { residential } \\
\text { land }\end{array}$ & -16.47 & -1.37 & 21.45 & 1.92 & 11.21 & 0.91 & 9.41 & 0.73 & 45.24 & 3.40 \\
\hline $\begin{array}{l}\text { Other } \\
\text { construction } \\
\text { land }\end{array}$ & 22.29 & 4.72 & -9.88 & -1.69 & -2.45 & -0.46 & 123.94 & 23.73 & 746.11 & 65.33 \\
\hline Unused land & 7.68 & 3.93 & -6.23 & -2.66 & -8.55 & -4.22 & -1.80 & -1.12 & 0.29 & 0.19 \\
\hline
\end{tabular}

\subsection{Comprehensive land use transition}

As shown in Fig. 5 that the spatial distribution of dynamic degree of comprehensive land use in Guizhou Province shows obvious differences in five periods. With the development of time, the dynamic transition of land use in Guizhou Province showed a trend of decreasing first and then increasing as a whole, which decreased from $5.96 \%$ for $1990-1995$ to $2.06 \%$ for $2005-2010$, and increased to $6.37 \%$ for $2010-2015$. During period of $1990-2000$ and 2000-2005, the high concentration of comprehensive land use transition was mainly concentrated in Zunyi in the north and Qiandongnan in the east of Guizhou Province. From 2005 to 2015, the high value of comprehensive land use dynamics was mainly concentrated in Guiyang, Bijie, Anshun, and Qiannan. During the period of 1990-2005, the dynamic degree of comprehensive land use continued to rise. Mountain cultivated land, unused land, and grassland are gradually transformed from agricultural land to non-agricultural land. On the whole, the dynamic transition of comprehensive land use change in the central region was more obvious than that in other regions. 


\subsection{Spatiotemporal analysis of land use transition}

\subsubsection{Quantitative analysis of land use transition}

We sorted the transition of land use type with large transition degree based on the area size, and found that 19 types of atlas units accounted for the most significant changes in the area of map units (Table 4). From 1990 to 2015, the cultivated land $\rightarrow$ forestland (code 102), cultivated land $\rightarrow$ grassland (code 103), forestland $\rightarrow$ cultivated land (code 201), forestland $\rightarrow$ grassland (code 203), grassland $\rightarrow$ cultivated land (code 301 ), and grassland $\rightarrow$ forestland (code 302) that were the most significant atlas units, accounting for $78.89 \%$ of the total unit area, mainly distributed in the south and northeast of Guizhou Province. The second is the atlas type of "forest land $\rightarrow$ other construction land (code 207), cultivated land $\rightarrow$ urban land (code 105)", accounting for $7.87 \%$ of the total atlas unit area, mainly distributed in the middle. The third is the mutual conversion of urban land, cultivated land, and rural residential land, accounting for $2.67 \%, 3.21 \%$, and $2.93 \%$ of the total map unit area, respectively. With the development of time, the transition categories mainly concentrated for 1990-1995, 1995-2000, and 2000-2005. For 2005-2010 and 2010-2015, the transfer areas of urban land, rural residential land, and other construction land began to change significantly. The areas of grassland converted to unused land, cultivated land, and forest land were $81,940,72,044$, and $41,039 \mathrm{~km}^{2}$, respectively, and the cumulative conversion rates was $37.72 \%$, the areas of the three transferred to grassland were $80,646,68,145$, and $41,039 \mathrm{~km}^{2}$, respectively. The cumulative transfer rates were $37.57 \%$, and the net transfer rates of grassland was $0.15 \%$.

Table 4

Main land use transition processes in Guizhou Province from 1990 to 2015.

\begin{tabular}{|c|c|c|c|c|c|c|c|c|c|c|c|c|}
\hline \multirow[t]{2}{*}{ Order } & \multirow[t]{2}{*}{ Code } & \multirow{2}{*}{$\begin{array}{l}\text { land use } \\
\text { type } \\
\text { conversion }\end{array}$} & \multicolumn{2}{|c|}{ 1990-1995 } & \multicolumn{2}{|c|}{ 1995-2000 } & \multicolumn{2}{|c|}{$2000-2005$} & \multicolumn{2}{|c|}{$2005-2010$} & \multicolumn{2}{|c|}{$2010-2015$} \\
\hline & & & $\begin{array}{l}\text { Transfer } \\
\text { area/km² }\end{array}$ & $\begin{array}{l}\text { Change } \\
\text { ratio/\% }\end{array}$ & $\begin{array}{l}\text { Transfer } \\
\text { area/km² }\end{array}$ & $\begin{array}{l}\text { Change } \\
\text { ratio/\% }\end{array}$ & $\begin{array}{l}\text { Transfer } \\
\text { area/km² }\end{array}$ & $\begin{array}{l}\text { Change } \\
\text { ratio/\% }\end{array}$ & $\begin{array}{l}\text { Transfer } \\
\text { area/km² }\end{array}$ & $\begin{array}{l}\text { Change } \\
\text { ratio/\% }\end{array}$ & $\begin{array}{l}\text { Transfer } \\
\text { area/km² }\end{array}$ & $\begin{array}{l}\text { Change } \\
\text { ratio/\% }\end{array}$ \\
\hline 1 & 102 & $\mathrm{CuL} \rightarrow \mathrm{FoL}$ & 938.29 & 25.99 & 59.35 & 1.66 & 530.61 & 21.66 & 82.50 & 4.16 & 0.46 & 0.04 \\
\hline 2 & 103 & $\mathrm{CuL} \rightarrow \mathrm{GrL}$ & 387.78 & 10.74 & 53.05 & 1.49 & 55.73 & 2.27 & 75.89 & 3.83 & 2.97 & 0.23 \\
\hline 3 & 104 & $\mathrm{CuL} \rightarrow \mathrm{WaL}$ & 4.73 & 0.13 & 7.16 & 0.20 & 2.16 & 0.09 & 83.43 & 4.21 & 43.87 & 3.36 \\
\hline 4 & 105 & $\mathrm{CuL} \rightarrow \mathrm{UrL}$ & 9.85 & 0.27 & 32.75 & 0.92 & 5.62 & 0.23 & 62.86 & 3.17 & 179.48 & 13.74 \\
\hline 5 & 106 & $\mathrm{CuL} \rightarrow \mathrm{RuRL}$ & 4.54 & 0.13 & 22.40 & 0.63 & 3.15 & 0.13 & 12.16 & 0.61 & 52.70 & 4.03 \\
\hline 6 & 107 & $\mathrm{CuL} \rightarrow \mathrm{OtL}$ & 5.32 & 0.15 & 5.61 & 0.16 & 0.26 & 0.01 & 48.51 & 2.45 & 439.39 & 33.64 \\
\hline 7 & 201 & $\mathrm{FoL} \rightarrow \mathrm{CuL}$ & 132.34 & 3.67 & 1002.02 & 28.09 & 159.94 & 6.53 & 22.12 & 1.12 & 7.61 & 0.58 \\
\hline 8 & 203 & $\mathrm{FoL} \rightarrow \mathrm{GrL}$ & 700.21 & 19.40 & 1403.52 & 39.35 & 95.41 & 3.90 & 245.79 & 12.40 & 11.24 & 0.86 \\
\hline 9 & 204 & FoL $\rightarrow$ WaL & 1.77 & 0.05 & 4.03 & 0.11 & 0.01 & 0 & 95.73 & 4.83 & 33.01 & 2.53 \\
\hline 10 & 205 & $\mathrm{FoL} \rightarrow \mathrm{UrL}$ & 3.07 & 0.08 & 1.28 & 0.04 & 0.25 & 0 & 13.46 & 0.68 & 31.11 & 2.38 \\
\hline 11 & 207 & $\mathrm{FoL} \rightarrow \mathrm{OtL}$ & 19.99 & 0.55 & 4.82 & 0.14 & 1.86 & 0.08 & 50.27 & 2.54 & 178.81 & 13.69 \\
\hline 12 & 301 & $\mathrm{GrL} \rightarrow \mathrm{CuL}$ & 77.02 & 2.13 & 390.57 & 10.95 & 483.26 & 19.73 & 33.05 & 1.67 & 4.18 & 0.32 \\
\hline 13 & 302 & $\mathrm{GrL} \rightarrow \mathrm{FoL}$ & 1244.40 & 34.47 & 517.09 & 14.50 & 1079.89 & 44.08 & 1049.53 & 52.94 & 3.31 & 0.25 \\
\hline 14 & 304 & $\mathrm{GrL} \rightarrow \mathrm{WaL}$ & 2.47 & 0.07 & 7.43 & 0.21 & 2.80 & 0.11 & 59.03 & 2.98 & 11.87 & 0.91 \\
\hline 15 & 307 & $\mathrm{GrL} \rightarrow \mathrm{OtL}$ & 3.38 & 0.09 & 2.03 & 0.06 & 0.93 & 0.04 & 24.80 & 1.25 & 157.36 & 12.05 \\
\hline 16 & 401 & $\mathrm{WaL} \rightarrow \mathrm{CuL}$ & 7.07 & 0.20 & 0.78 & 0.02 & 0.71 & 0.03 & 0.27 & 0.01 & 0.81 & 0.06 \\
\hline 17 & 501 & $\mathrm{UrL} \rightarrow \mathrm{CuL}$ & 12.43 & 0.34 & 3.83 & 0.11 & 0.13 & 0.01 & 0.20 & 0.01 & 1.48 & 0.11 \\
\hline 18 & 601 & RuRL $\rightarrow$ CuL & 19.57 & 0.54 & 1.94 & 0.05 & 0.49 & 0.02 & 1.87 & 0.09 & 0.61 & 0.05 \\
\hline 19 & 702 & $\mathrm{OtL} \rightarrow \mathrm{FoL}$ & 1.67 & 0.05 & 18.90 & 0.53 & 0.05 & 0 & 0.13 & 0.01 & 2.51 & 0.19 \\
\hline
\end{tabular}

Note: CuL-cultivated land, FoL-forest land, GrL-grassland, WaL-water land, UrL-urban land, RuRL-rural residential land, OtL-other construction land, UnL-unused land.

\subsubsection{Analysis of land use rising}

As shown in Fig. 6, during 1990-1995, the area of unchanged land use in Guizhou Province was 172,498.87 km², and the area of changed land use was $3609.90 \mathrm{~km}^{2}$. The areas of newly added forest land and grassland were the largest in the change area, with area of 2189.29 and $1095.85 \mathrm{~km}^{2}$, respectively. The areas of newly added cultivated land, urban land, and other construction land were $252.80,16.83$, and $29.58 \mathrm{~km}^{2}$ respectively. The areas of newly added water area, rural residential land, and unused land were the smallest. During 1995-2000, the area of unchanged land use was 
$172,542.32 \mathrm{~km}^{2}$, and the area of changed land use was $3566.87 \mathrm{~km}^{2}$. The newly added areas of cultivated land, forest land, and grassland were 1401.23 , 1601.17 , and $1465.12 \mathrm{~km}^{2}$, respectively. From 2000 to 2005 , the area of unchanged land use was $173,659.16 \mathrm{~km}^{2}$, and the area of changed land use was $2449.63 \mathrm{~km}^{2}$. The areas of newly added cultivated land, forest land, and grassland that accounted for $26.37 \%, 66.08 \%$, and $6.20 \%$ of the change areas, respectively. From 2005 to 2010, the area of unchanged land use was 174,126.49 km², and the area of changed land use was $1982.63 \mathrm{~km}^{2}$. The areas of newly added cultivated land, forestland, and grassland accounted for $2.90 \%, 57.21 \%$, and $16.38 \%$, respectively. For $2010-2015$, the area of unchanged land use was $176,109.18 \mathrm{~km}^{2}$, and the area of changed land use was $1277.51 \mathrm{~km}^{2}$, respectively. The areas of newly added cultivated land, forestland, and grassland accounted for $1.33 \%, 0.56 \%$, and $1.23 \%$, respectively.

The areas of newly added forest land, grassland, and urban and rural construction land in central Guizhou Province were the largest. The areas of newly added grassland and cultivated land were the largest in Qiannan and Tongren. Guizhou Province mainly increased forestland and grassland during 1990 -1995 and 1995-2000; during 2000-2005, 2005-2010, and 2010-2015, it mainly increased rural residential land, especially urban land and other construction land. Among them, the central part of Guizhou Province was mainly newly added urban and rural construction land. In the five periods, the main newly added land use types in Guizhou Province were cultivated land, urban land, and rural construction land. But the increase rates of urban and rural construction land had far exceeded that of cultivated land in the latter period.

\subsubsection{Analysis of land use shrinking}

As shown in Fig. 7 that the shrinking areas of cultivated land, forest land, and grassland in Guizhou Province were the largest during 1990-1995, their areas were $1350.93,862.47$, and $1335.79 \mathrm{~km}^{2}$, respectively; the second is rural residential land and urban land, accounting for $0.70 \%$ and $0.48 \%$, respectively. The shrinking areas of other construction land and unused land were smaller, accounting for less than $0.21 \%$. During $1995-2000$, the total shrinking area of land use was $3566.87 \mathrm{~km}^{2}$, accounting for $2.03 \%$. The shrinking areas of cultivated land, forest land, and grassland were 180.33 , 2417.54 , and $923.32 \mathrm{~km}^{2}$, respectively, followed by $23.70 \mathrm{~km}^{2}$ of other construction land. For 2000-2005, the total shrinking area of land use was $2449.63 \mathrm{~km}^{2}$, accounting for $1.39 \%$. The shrinking areas of cultivated land, forest land, and grassland were $597.53,258.45$, and $1576.56 \mathrm{~km}^{2}$, respectively. From 2005 to 2010 , the total shrinking area of land use was $1982.63 \mathrm{~km}^{2}$, accounting for $1.13 \%$. The shrinking areas of cultivated land, forest land, and grassland were 365.34, 429.73, and $1177.55 \mathrm{~km}^{2}$, respectively. From 2010 to 2015 , the total shrinking area of land use was $1277.51 \mathrm{~km}{ }^{2}$, accounting for $0.73 \%$. The shrinking areas of cultivated land, forest land, and grassland were $719.32,274.69$, and $215.42 \mathrm{~km}^{2}$ respectively, followed by rural residential land and other construction land, accounting for $2.14 \%$ and $2.63 \%$, respectively.

The shrinking land use types in the west and northwest of Guizhou Province were grassland and cultivated land, which were consistent with the newly increased land use types. However, in the eastern part of Guizhou Province, the main type of shrinking land was cultivated land. From 1990 to 2015 , the areas and structures of different shrinking land use types in Guizhou Province had a high spatial similarity with newly added land use types. It is worth noting that the shrinking areas of forestland, grassland, and cultivated land had increased compared with the previous period, while the shrinking areas of urban land, rural residential land, and other construction land had decreased compared with the previous period. This feature was particularly evident in Zunyi, Tongren, Qiandongnan, Qiannan, Qianxinan, Liupanshui, and Bijie areas. with the rapid development of urbanization in recent years, the demand for a large amount of construction land is difficult to meet, which has led to an increase in the amount of cultivated land occupied by urban land in some areas (Li et al. 2017).

\subsection{Evolution characteristics of landscape fragmentation}

As shown in Fig. 8 that the PD and NP of prefecture-level cities showed a similar relationship from 1990 to 2015, basically decreasing first and then increasing. From 1990 to 2015, the PD and NP in Bijie, Liupanshui, Guiyang, Qiannan, Qianxinan, Qiandongnan, Zunyi, and Tongren showed the biggest fluctuation, showing a "W" shape, both of them reached a turning point for 2000. By 2015, the PD and NP were at their maximum, the reason is that a large number of local infrastructures, roads, and urban and rural construction land expansion that have led to the strongest disturbance of regional land use landscape patches, and the spatial fragmentation was more and more obvious. The prefecture-level cities with the most obvious changes were Bijie (PD: 0.4468 number $\cdot \mathrm{km}^{-1}$, NP: 21940), Guiyang (PD: 0.3712 number $\mathrm{km}^{-1}$, NP: 5740), and Tongren (PD: 0.4123 number $\mathrm{km}^{-1}$, NP: 16,259), and Zunyi (PD: 0.4001 number $\cdot k m-1$, NP: 24,199), followed by Anshun (PD: 0.2371 number $\cdot \mathrm{km}^{-1}$, NP: 4498), Qiandongnan (PD: 0.2491 number $\cdot \mathrm{km}^{-1}$ ), NP:14,054), Qiannan (PD: 0.2479 number $\left.\cdot \mathrm{km}^{-1}, \mathrm{NP}: 14,446\right)$, and Qiannan (PD: 0.4123 number $\left.\cdot \mathrm{km}^{-1}, \mathrm{NP}: 24,199\right)$.

As shown in Fig. 9 that the changes in LPI and LSI of each prefecture-level city in Guizhou Province showed opposite trends during the period of 19902015. The LSI in the Anshun, Bijie, Guiyang, Qiandongnan, Qiannan, Tongren, and Zunyi showed an overall decreasing trend, while the LSI in the Liupanshui and Qianxinan showed an increasing trend. In terms of LPI, the Qiandongnan, Guiyang, and Zunyi showed a trend of increasing demand on the whole, while Anshun, Bijie, Liupanshui, Qiannan, and Tongren showed a trend of continuous decrease on the whole, and only the LSI in the Qianxinan remained basically unchanged. The LPI of Guizhou Province was mainly dominated by forestland, cultivated land, and grassland. From 1990 to 2015 , forestland and grassland showed an increasing trend, while cultivated land showed a change of decreasing first and then increasing. During 1990-2000, the area of cultivated land showed expansion, while the area of forest land decreased first. On the whole, the LPI of remote cultivated land was larger than that of forest land. From 2000 to 2015, the patches of forest land and grassland increased successively. For 1990-2015, the urban land, rural residential land, and other construction land in prefecture-level cities expanded rapidly under the strong influence of local people, resulting in the segmentation and encroachment of regional landscape types, and enhancing in the diversification and fragmentation of landscape types.

\subsection{Analysis of landscape diversity}

Page $8 / 24$ 
As shown in Fig. 10, the PRD and SHDI in Guizhou Province showed basic consistency in spatial distribution during 1990-2015, with high values mainly concentrated in the Guiyang, Anshun, and Liupanshui, and gradually migrating from the central region to the western region. The low values were mainly distributed in Zunyi in the north, Qiandongnan in the east, and Qiannan in the south of Guizhou Province. From 1990 to 2015 , the CONTAG index was mainly distributed in the Zunyi, Tongren, Guiyang, and Qiannan, which were concentrated in the central region from the periphery with time passing. From 1990 to 2015, it is clear that the evolution of landscape patch types showed high fragmentation and spread connectivity. With the continuous improvement of the social economy and the influence of human activities, i.e., artificial ecological governance, road traffic construction, communication network construction, and rural tourism construction), the land use patches in the study area were constantly divided, which led to the continuous decentralization of the patch types within the landscape, forming a variety of landscape utilizes. The urban land expansion, the increase of roads and land for rural residents, and the decrease of cultivated land make the natural landscape patch types continuously segmented and derived more single patches (Traviglia and Torsello 2017). As a result, the landscape characteristics area was fragmented, with high patch connectivity, maximum diversity, and relative richness, and finally generating a high degree of landscape spatial heterogeneity.

\section{Discussion}

\subsection{Driving mechanism of land use transition and landscape pattern evolution}

The Walds statistics and standard error were used as estimation factors to represent explanatory variables in the relative weight model of each regression coefficient, and the contribution strength of each explanatory variable could be evaluated by combining significant (Liang et al. 2020). As shown in Fig. 11 and Table 5, the ROC test statistics of all land use types in Guizhou Province were over 0.70, indicating that the selected driving factors showed good explanatory ability in explaining land use transition and landscape pattern evolution. For 1990-2015, M and B were important factors affecting the transition of cultivated land, showing a strong positive correlation. The contributions of $C, L$, and $P$ to cultivated land were also strong, but which showed a negative correlation. Forest land was mainly affected by C, D, M, Q, and N. D and L were negative explanatory variables of grassland, indicating that grassland was less likely to occur in population distribution areas. GDP, topographic relief, and population had become important factors restricting the development of urban land expansion. Rural residents were mainly affected by local topography, population, and GDP. Other construction land was mainly affected by population, traffic lines, and terrain factors. In addition, landscape pattern evolution and land use transition are mutually influencing processes (Zebisch et al. 2001), and local soil organic matter still plays an important role in their evolution. Forestland, grassland, and cultivated land were mainly distributed in high slope and altitude remote areas, and the factors were highly constrained by terrain. Urban land, rural residential land, and other construction land were mainly affected by socioeconomic factors. In addition, elevation, slope, nearest river, distance to the nearest town center, and distance to the nearest county center that were positive explanatory abilities of construction land. Guizhou Province is a complex terrain area with high mountains, low mountains, valleys, trough valley, and other terrain. The local topographic conditions are the main factors affecting land use transition and landscape pattern evolution, followed by socioeconomic factors. 
Table 5

Contribution capacity of each factor driving.

\begin{tabular}{|c|c|c|c|c|c|c|c|c|}
\hline \multirow[t]{2}{*}{$\begin{array}{l}\text { Variable } \\
\text { code }\end{array}$} & $\begin{array}{l}\text { Cultivated } \\
\text { land }\end{array}$ & $\begin{array}{l}\text { Forest } \\
\text { land }\end{array}$ & Grassland & $\begin{array}{l}\text { Water } \\
\text { land }\end{array}$ & $\begin{array}{l}\text { Urban } \\
\text { land }\end{array}$ & $\begin{array}{l}\text { Rural residential } \\
\text { land }\end{array}$ & $\begin{array}{l}\text { Other construction } \\
\text { land }\end{array}$ & $\begin{array}{l}\text { Unused } \\
\text { land }\end{array}$ \\
\hline & $\operatorname{Exp}(\beta)$ & $\operatorname{Exp}(\beta)$ & $\operatorname{Exp}(\beta)$ & $\operatorname{Exp}(\beta)$ & $\operatorname{Exp}(\beta)$ & $\operatorname{Exp}(\beta)$ & $\operatorname{Exp}(\beta)$ & $\operatorname{Exp}(\beta)$ \\
\hline$A$ & -4.264 & 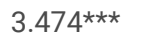 & -5.73 & 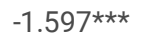 & $-0.335^{\star \star \star}$ & $-1.222^{\star \star \star}$ & 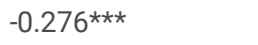 & 99.379 \\
\hline B & 21.42 & $0.606^{\star \star \star}$ & 47.24 & -71.568 & -39.608 & 24.737 & 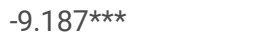 & -968.492 \\
\hline C & -79.912 & 23.301 & $5.594^{\star \star \star}$ & $-6.705^{\star \star \star}$ & -42.954 & -105.307 & -51.221 & 182.155 \\
\hline$D$ & -63.001 & -28.692 & -80.457 & 53.433 & 58.524 & $-8.675^{\star \star \star}$ & 24.381 & 415.286 \\
\hline$E$ & -0.704 & $0.156^{\star \star \star}$ & 0.590 & -19.789 & 1.389 & $0.066^{\star \star \star}$ & 0.958 & 1.773 \\
\hline $\mathrm{F}$ & 0.945 & -0.728 & $0.473^{\star \star \star}$ & 6.435 & -15.621 & -2.427 & -2.599 & $0.338 * \star \star$ \\
\hline G & -1.469 & -0.171 *** & -1.323 & -3.431 & -9.387 & -0.457 & -2.185 & -3.751 \\
\hline $\mathrm{H}$ & -0.405 & -0.428 & 1.632 & -2.207 & -0.482 & $0.126^{\star \star \star}$ & 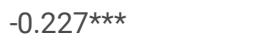 & 4.403 \\
\hline I & $-0.032^{\star \star \star}$ & -1.327 & 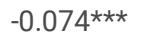 & 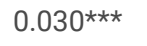 & -0.808 & 0.683 & 0.356 & -5.418 \\
\hline J & -0.909 & $0.241^{\star \star \star \star}$ & 3.057 & -0.775 & -1.644 & 1.767 & -1.031 & 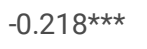 \\
\hline K & 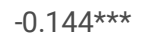 & 0.630 & -2.387 & 0.741 & $0.482^{\star \star \star}$ & -0.552 & -0.838 & 2.241 \\
\hline L & -40.279 & $-57.326^{\star \star \star}$ & -80.746 & $5.458 * \star \star$ & -47.456 & -63.94 & -22.503 & -1518.377 \\
\hline$M$ & 136.801 & -86.43 & 20.973 & 22.951 & 75.903 & 115.798 & 54.849 & -87.037 \\
\hline $\mathrm{N}$ & $4.829 * \star \star$ & 16.969 & 12.014 & -27.632 & 19.377 & 22.269 & 14.204 & $9.822^{\star \star \star}$ \\
\hline 0 & $8.592^{\star \star \star}$ & $-1.455^{\star \star \star}$ & 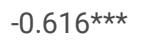 & 16.966 & 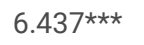 & $3.050 * \star \star$ & 4.187 & -564.663 \\
\hline$P$ & -42.394 & 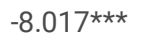 & 1.684 & 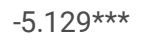 & -7.97 & -6.454 & $-3.718 * \star \star$ & -659.99 \\
\hline Q & $12.581^{\star \star \star ~}$ & 76.242 & $17.475^{\star \star \star}$ & $-7.725^{\star \star \star}$ & 39.422 & 60.572 & 22.499 & 1531.432 \\
\hline $\mathrm{R}$ & -1.36 & 1.958 & 0.298 & -7.021 & -1.119 & -0.958 & -1.145 & 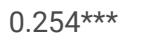 \\
\hline$S$ & 2.637 & $1.145^{\star \star \star}$ & 1.702 & -2.678 & 6.557 & 5.887 & 3.786 & 4.663 \\
\hline $\mathrm{T}$ & $-0.118^{\star \star \star}$ & 0.251 & 0.198 & -0.395 & $0.237^{\star \star \star}$ & 0.139 & 0.146 & 0.607 \\
\hline U & -9.859 & $-1.143^{\star \star \star}$ & -4.637 & $-0.733^{\star \star \star}$ & -50.064 & -43.779 & -31.964 & -37.593 \\
\hline Constant & 0.809 & -0.283 & -0.61 & 3.584 & 3.445 & 1.23 & 1.824 & 1.357 \\
\hline ROC & 0.863 & 0.912 & 0.893 & 0.886 & 0.869 & 0.910 & 0.902 & 0.885 \\
\hline
\end{tabular}

On the whole, Guizhou Province has undergone major changes in land use from 1990 to 2015, which were mainly manifested in the mutual conversion of grassland, cultivated land, and forest land, as well as the mutual conversion of urban land, rural residential land, other construction land, and cultivated land. Under the dual influence of local natural conditions and human activities, the change frequency of cultivated land to forestland and grassland was the highest. On the one hand, regional climate, soil type, and soil organic quality factors lead to a large amount of conversion from grassland to cultivated land and forest land (Guo et al. 2019). On the other hand, Guizhou Province has made great efforts to build the ecological environment in recent years, the local government has implemented the comprehensive rocky desertification and the policy of returning cultivated land to forest, so the areas of forest land and grassland has been replenished. Under the mechanism of various factors, various land use types underwent drastic transformation, and at the same time, landscape pattern changed in spatial consistency.

\subsection{Ecological significance of land use transition and landscape pattern evolution}

Land use transition and landscape pattern evolution are a process of mutual influence (Deng et al. 2009). In the process of land use type evolution, local change produces overall horizontal spatial chain change, and finally presents landscape heterogeneity (Sklenicka and Pixova 2004). Scientifically mastering the evolution path of land use transition and the dynamic direction of landscape pattern can help to balance regional socioeconomic development and powerful measures of ecological environmental protection. In recent years, China has been pursuing rapid socioeconomic development and has made outstanding achievements in various fields. At the same time, the rationality of regional ecological environment protection and efficient utilization of land resources is the final guarantee for the construction of national ecological civilization. This study mainly analyzed the spatiotemporal characteristics of the transition of land use types and the evolution of landscape pattern in Guizhou Province, which can help in local long-term policy formulation and ecological protection is of great significance. With the clear requirements of ecological civilization construction in China, mountainous 
areas should bear more responsibility for ecological management. In recent years, the relevant departments of Guizhou Province cooperated with each other has scientifically implemented a series of land remediation projects and ecological protection projects according to local natural geographical characteristics and socioeconomic development trends, which have improved the regional ecological environment quality and enhanced land use efficiency (Fig. 12), such as rock desertification governance and ecological migration projects. According to the characteristics of different types and stages of land use transition and landscape pattern evolution, it is of great significance to adopt the regional expansion and contraction strategies to drive the landscape ecological level of the surrounding area, so as to improve the ecological effect of this complex mountain area.

\subsection{Policy implications in mountainous areas}

Land sustainable management and ecological protection has always been a hot issue from the government and academic circles. It is very necessary to formulate a series of land use and ecological protection policies for Karst, a typical ecologically fragile area. With rapid population growth and lack of cultivated land resources in mountainous areas, forest land to maintain ecological environment is a key project in the region. In recent decades, although China has formulated a series of policies on returning farmland to forest and forestry management, which have significantly improved the ecological environment of the whole region, there are still some problems in the balance between forestry management and land use policy. Based on the results of this study, we further put forward some reasonable suggestions to promote the forest management, land use transition, and landscape planning in Karst areas. (1) Policy makers need to combine hydrogeology and soil type characteristics in Karst regions for land use protection and plantation forests in high-altitude areas. (2) The government should actively encourage farmers to return farmland and grassland to forest in areas with steep slopes greater than $25^{\circ}$, increase vegetation coverage and reduce soil erosion; there should also be a compensation system for farmers. (3) Collaborative cooperation among multiple departments, interactive policy consultation, and joint training of comprehensive management staff to carry out biological, chemical and physical engineering to enhance land production capacity and improve the fragile ecological environment of Karst, so as to maximize the ecological environment for ecological and economic benefits Beneficial. (4) Actively improving farmer's knowledge level, cultivating their awareness of ecological environment protection, reducing the damage to the forest ecological environment as far as possible in the planting process, and eliminating the waste of land resources. In essence, efficient land use and ecological environment protection can be realized only from the main body of farmers. (5) Actively introducing high and new technologies and industries to promote traditional agriculture to be replaced by modern mechanical farming system. Traditional land use and resource management methods should improve technology and machinery investment by increasing the intensity of modern agriculture. At the national and regional levels, the balance between ecological environment, land use, and social economy should be comprehensively coordinated. In the following research process, promoting the progress of social civilization and orderly ecological environment is an important topic, which is also worthy academic topic for in-depth discussion.

\section{Conclusions}

This study took Guizhou Province in mountain areas of typical Karst as the research object and revealed the mechanism process of land use transition and landscape pattern evolution in the past 25 years through geographic information atlas and landscape pattern method. Some interesting practical conclusions are as follows: exploring the land use transition and landscape pattern evolution laws and their spatiotemporal characteristics in typical

Karst areas, the internal change mechanism between them was clarified. Analyzing the formation principle of their differences in spatiotemporal was an inevitable requirement of the major strategy of national guidance for regional development, and also plays an important strategic role in balancing ecological governance and land use optimization management in accordance with local conditions in each region of the country. At the same time, it also can provide theoretical reference for decision-makers in different regions.

\section{Declarations}

\section{Funding}

Guizhou Normal University Graduate Innovation Fund Project [Grant number: YC [2018]025].

\section{Acknowledgments}

This work was supported by Guizhou Normal University Graduate Innovation Fund Project [Grant number: YC [2018]025].

\section{CRediT authorship contribution statement}

Quan Wang contributed to conceptualization and methodology, software writing-original draft preparation. Xuepiao Bai contributed to formal analysis, writing - review \&editing, validation.

\section{Declaration of interests}

The authors declare that they have no known competing financial interests or personal relationships that could have appeared to influence the work reported in this paper.

\section{Availability of data and materials}


The data sets generated and analyzed during the current study are not publicly available due to the signing of the confidentiality agreement but are available from the corresponding author on reasonable request.

\section{Consent to publish}

As a result of the research, we unanimously agree that this paper can be published in your journal.

\section{References}

1. Abbas Z, Yang G, Zhong YJ, Hao YL (2021) Spatiotemporal Change Analysis and Future Scenario of LULC Using the CA-ANN Approach: A Case Study of the Greater Bay Area, China. Land 10, 6, 584.

2. Achieng T, Maciejewski K, Dyer M, Biggs R (2020) Using a Social-ecological Regime Shift Approach to Understand the Transition from Livestock to Game Farming in the Eastern Cape, South Africa. Land 9(4), 97.

3. Antrop M (2000) Background concepts for integrated landscape analysis. Agriculture ecosystems environment 77(1-2): 17-28.

4. Bessah E, Bala A, Agodzo SK, Okhimamhe AA, Boakye EA, Ibrahim SU (2019) The impact of crop farmers' decisions on future land use, land cover changes in Kintampo North Municipality of Ghana. International journal of climate change strategies and management 11(1): $72-87$.

5. Bessah E, Bala A, Agodzo SK, Okhimamhe AA, Boakye EA, Ibrahim SU (2019) The impact of crop farmers' decisions on future land use, land cover changes in Kintampo North Municipality of Ghana. International journal of climate change strategies and management 11(1): $72-87$.

6. Buyantuyev A, Wu JG (2007) Effects of thematic resolution on landscape pattern analysis. Landscape ecology 22(1): 7-13

7. Chen AL, Zhao XF, Yao L, Chen LD (2016) Application of a new integrated landscape index to predict potential urban heat islands. Ecological indicators 69, 828-835.

8. Chen GQ, Han MY (2015) Virtual land use change in China 2002-2010: Internal transition and trade imbalance. Land Use Policy 47, 55-65.

9. Cheng LL, Liu M, Zhan JQ (2020) Land use scenario simulation of mountainous districts based on Dinamica EGO model. Journal of mountain science 17(2): 289-303.

10. Corry RC (2005) Characterizing fine-scale pattern of alternative agricultural landscapes with landscape pattern indices. Landscape ecology 20(5): 591-608.

11. Costantini ML, Zaccarelli N, Mandrone S, Rossi D, Calizza E, Rossi L (2012) NDVI spatial pattern and the potential fragility of mixed forested areas in volcanic lake watersheds. Forest ecology and management 285, 133-141.

12. Dai XY, Zhou YQ, Ma WC, Zhou LG (2017) Influence of spatial variation in land use patterns and topography on water quality of the rivers inflowing to Fuxian Lake, a large deep lake in the plateau of southwestern China. Ecological engineering 99, 417-428.

13. De Pablo CL, Roldan-Martin MJ, De Agar PM (2012) Magnitude and Significance in Landscape Change. Landscape research 37(5): $571-589$.

14. Debnath J, Das N, Ahmed I (2020) An Attempt to Analyse the Driving Forces of Land Use Changes of a Tropical River Basin: A Case Study of the Muhuri River, Tripura, North-East India. International Journal of Ecology and Development 35(2):13-30.

15. Deng H, Zhang K, Wang F, Dang AR (2021) Compact or disperse Evolution patterns and coupling of urban land expansion and population distribution evolution of major cities in China, 1998-2018. Habitat International 108(34):102324.

16. Deng JS, Wang K, Hong Y, Qi JG (2009) Spatio-temporal dynamics and evolution of land use change and landscape pattern in response to rapid urbanization. Landscape and urban planning 92(3-4): 187-198.

17. Deng YH, Wang SJ, Bai XY, Tian YC, Wu LH, Xiao JY, Chen F, Qian QH (2018) Relationship among land surface temperature and LUCC, NDVI in typical karst area. Scientific reports $8,641$.

18. Drummond MA, Loveland TR (2010) land use Pressure and a Transition to Forest-cover Loss in the Eastern United States. BioScience 60(4): 286298.

19. Feng XH, An P, Li XG, Guo K, Yang C, Liu XJ (2018) Spatiotemporal heterogeneity of soil water and salinity after establishment of dense-foliage Tamarix chinensis on coastal saline land. Ecological engineering 121, 104-113.

20. Frazier AE (2019) Emerging trajectories for spatial pattern analysis in landscape ecology. Landscape ecology 34(9): $2073-2082$.

21. Garrigues S, Allard D, Baret F, Morisette J (2008) Multivariate quantification of landscape spatial heterogeneity using variogram models. Remote sensing of environment 112(1): 216-230.

22. Gibbes C, Havlick D G, Robb JR (2017) Land use and land cover in a transitioning militarized landscape. Journal of land use science 12(2-3): 182196.

23. Gomes LC, Bianchi FJJA, Cardoso IM, Schulte RPO, Arts BJM, Fernandes El (2020) Land use and land cover scenarios: An interdisciplinary approach integrating local conditions and the global shared socioeconomic pathways. Land use policy 97, 104723.

24. Guo CZ, Wu YY, Ni J, Guo YM (2019) Forest carbon storage in Guizhou Province based on field measurement dataset. Acta geochimica 38(1): 8-21.

25. Huang BQ, Huang JL, Pontius RG, Tu ZS (2018) Comparison of Intensity Analysis and the land use dynamic degrees to measure land changes outside versus inside the coastal zone of Longhai, China. Ecological indicators 89, 336-347.

26. Huang XF, Wang SJ, Zhou YC (2018) Soil organic carbon change relating to the prevention and control of rocky desertification in Guizhou Province, SW China. International journal of global warming 15(3): 315-332.

Page 12/24 
27. Kamwi JM, Mbidzo M (2020) Impact of land use and land cover changes on landscape structure in the dry lands of Southern Africa: a case of the Zambezi Region, Namibia. Geojournal. DOI10.1007/s10708-020-10244-x.

28. Kamwi JM, Chirwa PWC, Manda SOM, Graz PF, Katsch C (2015) Livelihoods, land use and land cover change in the Zambezi Region, Namibia. Population and environment 37(2): 207-230.

29. Kelarestaghi A, Jeloudar ZJ (2011) Land use/cover change and driving force analyses in parts of northern Iran using RS and GIS techniques. Arabian journal of geosciences 4(3-4): 401-411.

30. Lambin EF, Meyfroidt P (2010) Land use transitions: socio-ecological feedback versus socio-economic change. Land use policy 27(2): 108-118.

31. Li WB, Wang DY, Li H, Liu SH (2017) Urbanization-induced site condition changes of peri-urban cultivated land in the black soil region of northeast China. Ecological indicators 80, 215-223.

32. Liu JY, Ning J, Kuang WH, Xu XL, Zhang SW, Yan CZ, Li RD, Wu SX, Hu YF, Du GM, Chi WF, Pan T, Jing N (2018) Spatio-temporal patterns and characteristics of land use change in China during 2010-2015. Acta Geographica Sinica 73(5),789-802.

33. Liu JY, Liu ML, Deng XZ, Zhuang DF, Zhang ZX, Luo D (2002) The Land Use and Land Cover Change Database and Its Relative Studies in China. Journal of Geographical Sciences 12 (3): 275-282.

34. Liu JY, Liu JY, Kuang WH, Zhang ZX, Xu XL, Qin YW, Ning J, Zhou WC., Zhang SW, Li RD, Yan CZ, Wu SX, Shi XZ, Jiang N, Yu DS, Pan XZ, Chi WF (2014) Spatiotemporal Characteristics, Patterns, and Causes of land use Changes in China since the Late 1980s. Journal of Geographical Sciences 24 (2): 195-210.

35. Liu JY, Zhang ZX, Xu XL, Kuang WH, Zhou WC, Zhang SW, Li RD, Yan CZ, Yu DS, Wu SX, Nan J (2010) "Spatial Patterns and Driving Forces of Land Use Change in China during the Early 21st Century." Journal of Geographical Sciences 20 (4): 483-494.

36. Liang XY, Jin XB, Yang XH, Xu WY, Lin JH, Zhou YK (2020) Exploring cultivated land evolution in mountainous areas of Southwest China, an empirical study of developments since the 1980s. Land degradation development 32(2): 546-558.

37. Liang XY, Li YB, Shao JA, Ran CH (2020) Traditional agroecosystem transition in mountainous area of Three Gorges Reservoir Area. Journal of geographical sciences 30(2): 281-296.

38. Long HL, Li TT (2012) The coupling characteristics and mechanism of farmland and rural housing land transition in China. Journal of geographical sciences 22(3): 548-562.

39. Long HL, Qu Y, Tu SS, Zhang YN, Jiang YF (2020) Development of land use transitions research in China. Journal of geographical sciences 30(7): 1195-1214.

40. Long J, Nelson T, Wulder M (2010) Regionalization of Landscape Pattern Indices Using Multivariate Cluster Analysis. Environmental management 46(1): 134-142.

41. Meiyappan P, Jain AK (2012) Three distinct global estimates of historical land-cover change and land use conversions for over 200 years. Frontiers of earth science 6(2): 122-139

42. Morelli F, Pruscini F, Santolini R, Perna P, Benedetti Y, Sisti D (2013) Landscape heterogeneity metrics as indicators of bird diversity: Determining the optimal spatial scales in different landscapes. Ecological indicators 34, 372-379.

43. Müller K, Steinmeier C, Küchler M (2010) Urban growth along motorways in Switzerland. Landscape and urban planning 98(1): 3-12.

44. Ouedraogo I, Barron J, Tumbo SD, Kahimba FC (2016) Land Cover Transition in Northern Tanzania. Land Degradation Development 27(3): 682-692.

45. Overmars KP, de Koning, GHJ, Veldkamp A (2003) Spatial autocorrelation in multi-scale land use models. Ecological modelling 164 (2-3): $257-270$.

46. Poelmans L, Van Rompaey A (2009) Detecting and modelling spatial patterns of urban sprawl in highly fragmented areas: a case study in the Flanders-Brussels region. Landscape and Urban Planning 93 (1), 10-19.

47. Qiu BW, Zeng CY, Cheng CC, Tang ZH, Gao JY, Sui YP (2014) Characterizing landscape spatial heterogeneity in multisensor images with variogram models. Chinese geographical science 24 (3): 317-327.

48. Qu YB, Jiang GH, Li ZT, Tian YY (2019) Understanding rural land use transition and regional consolidation implications in China. Land use policy 82, 742-753.

49. Ren M, Wang ZJ, Wang ZT, Zeng YJ, He LY (2018) Grain size effect of karst mountainous urban landscape pattern indices in the central Guizhou: A case study of Anshun City. Chinese Journal of Ecology 37(10): 2018.

50. Sahoo S, Sil I, Dhar A, Debsarkar A, Das P, Kar A (2018) Future scenarios of land use suitability modeling for agricultural sustainability in a river basin. Journal of cleaner production 205, 313-328.

51. Shen ZH, Li YY, Yang K, Chen LF (2019) The emerging cross-disciplinary studies of landscape ecology and biodiversity in China. Journal of geographical sciences 29(7): 1063-1080.

52. Sklenicka P, Pixova K (2004) Importance of spatial heterogeneity to landscape planning and management. Ekologia-bratislava 23, $310-319$.

53. Sunde MG, He HS, Zhou B, Hubbart JA, Spicci A (2014) Imperviousness Change Analysis Tool (I-CAT) for simulating pixel-level urban growth. Landscape and urban planning 124, 104-108.

54. Tellman B, Eakin H, Janssen MA, de Alba F, Turner BL (2021) The role of institutional entrepreneurs and informal land transactions in Mexico City's urban expansion. World Development 140, 105374. 
55. Tian JF, Wang BY, Zhang CR, Li WD, Wang SJ (2020) Mechanism of regional land use transition in underdeveloped areas of China: A case study of northeast China. Land use policy 94, 104538.

56. Traviglia A, Torsello A (2017) Landscape Pattern Detection in Archaeological Remote Sensing. Geosciences 7(4),128.

57. Turnbull L, Wainwright $\mathrm{J}$ (2019) From structure to function: Understanding shrub encroachment in drylands using hydrological and sediment connectivity. Ecological indicators 98: 608-618.

58. Turner S, Pham TTH (2015) "Nothing Is Like It Was Before": The Dynamics between land use and Land-Cover, and Livelihood Strategies in the Northern Vietnam Borderlands. Land 4(4): 1030-1059.

59. Ullah M, Li J, Wadood B (2020) Analysis of Urban Expansion and its Impacts on Land Surface Temperature and Vegetation Using RS and GIS, A Case Study in Xi'an City, China. Earth Systems and Environment 4(3):583-597.

60. Wang J, Sun L, Wang Z, Shan J, Li M (2020) Effects of spatial grain size on different types of cultivated land landscape pattern in fragmented agricultural landscapes based on gf-2 imagery. IOP Conference Series Earth and Environmental Science 502, 012044.

61. Wang JL, Lu YH, Zeng Y, Zhao ZJ, Zhang LW, Fu BJ (2014) Spatial heterogeneous response of land use and landscape functions to ecological restoration: the case of the Chinese loess hilly region. Environmental earth sciences 72(7): 2683-2696.

62. Wang L, Wu L, Zhang W (2021) Impacts of land use change on landscape patterns in mountain human settlement: The case study of Hantai District (Shaanxi, China). Journal of mountain science 18(3): 749-763.

63. Wang WJ, Guo HC, Chuai XW, Dai C, Lai L, Zhang M (2014) The impact of land use change on the temporospatial variations of ecosystems services value in China and an optimized land use solution. Environmental science policy 44, 62-72.

64. Yang LY, Sun ZH, Li JF, Shi L, Kong H, Yang YY, Li T (2021) Spatiotemporal patterns and driving forces of land use and land-cover change in the Mu Us Sandy Land, China from 1980 to 2018. Arid land research and management. DOI10.1080/15324982.2021.1933648.

65. Yang QY, Jiang ZC, Ma ZL, Luo WQ, Xie YQ, Cao JH (2013) Relationship between karst rocky desertification and its distance to roadways in a typical karst area of Southwest China. Environmental earth sciences 70(1): 295-302.

66. Yeh CT, Huang SL (2009) Investigating spatiotemporal patterns of landscape diversity in response to urbanization. Landscape and urban planning 93(2-4): 151-162.

67. Yuan H, Zhang RQ (2010) Changes in wetland landscape patterns on Yinchuan Plain, China. International journal of sustainable development and world ecology 17(3): 236-243.

68. Yue QX, Xiao MS, Xiang BK, Jian P, Yun LC (2008) Adapting the RUSLE and GIS to model soil erosion risk in a Mountains karst watershed, Guizhou Province, China. Environmental monitoring and assessment 141(1-3): 275-286.

69. Zebisch M, Wechsung F, Kenneweg $\mathrm{H}$ (2004) Landscape response functions for biodiversity - assessing the impact of land use changes at the county level. Landscape and urban planning 67(1-4): 157-172.

70. Zhang K, Yu Z, Li X, Zhou W, Zhang D (2007) Land use change and land degradation in China from 1991 to 2001. Land degradation development 18(2): 209-219.

71. Zhang B, Xia C (2021) The effects of sample size and sample prevalence on cellular automata simulation of urban growth. International Journal of Geographical Information Science. DOI10.1080/13658816.2021.1931237.

72. Zheng QW, Su WC, Zhang FT, Zhou ZQ (2019) Evaluation of Water Resources Security in the Karst Region from the "Man-Land-Water" Perspective: A Case Study of Guizhou Province. Water 11(2), 224.

73. Zhou QW, Wei XC, Zhou X, Cai MY, Xu YX (2019) Vegetation coverage change and its response to topography in a typical karst region: the Lianjiang River Basin in Southwest China. Environmental earth sciences 78(6), 191.

74. Zhu FK, Zhang FR, Ke XL (2018) Rural industrial restructuring in China's metropolitan suburbs: Evidence from the land use transition of rural enterprises in suburban Beijing. Land use policy 74: 121-129.

75. Zhu FK, Zhang FR, Li C, Zhu TF (2014) Functional transition of the rural settlement: Analysis of land use differentiation in a transect of Beijing, China. Habitat international 41, 262-271.

\section{Figures}


(a)

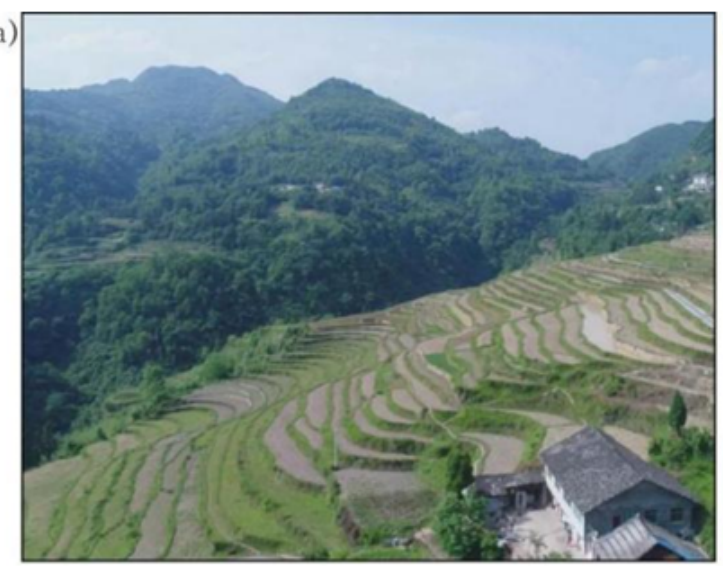

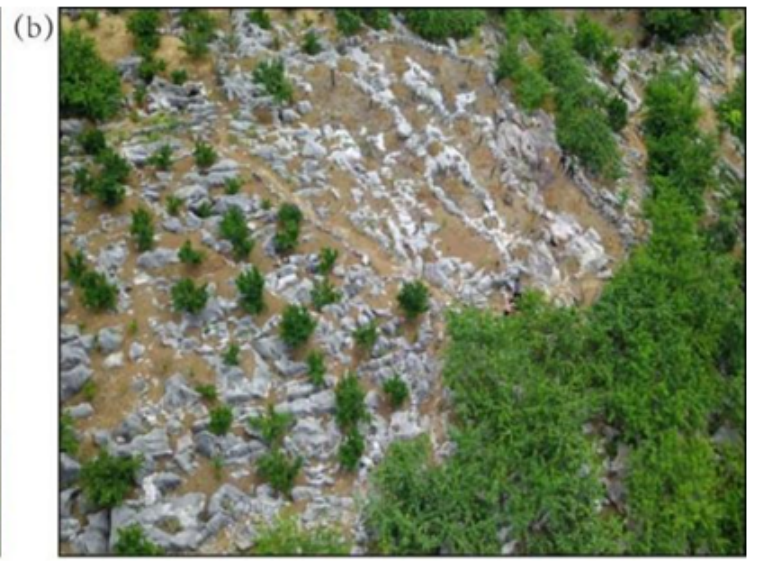

Figure 1

The landscape of rural and rocky desertification in Guizhou Province. (a): Distribution of cultivated land and rural settlements in mountainous areas, (b): Afforestation in rocky desertification area.

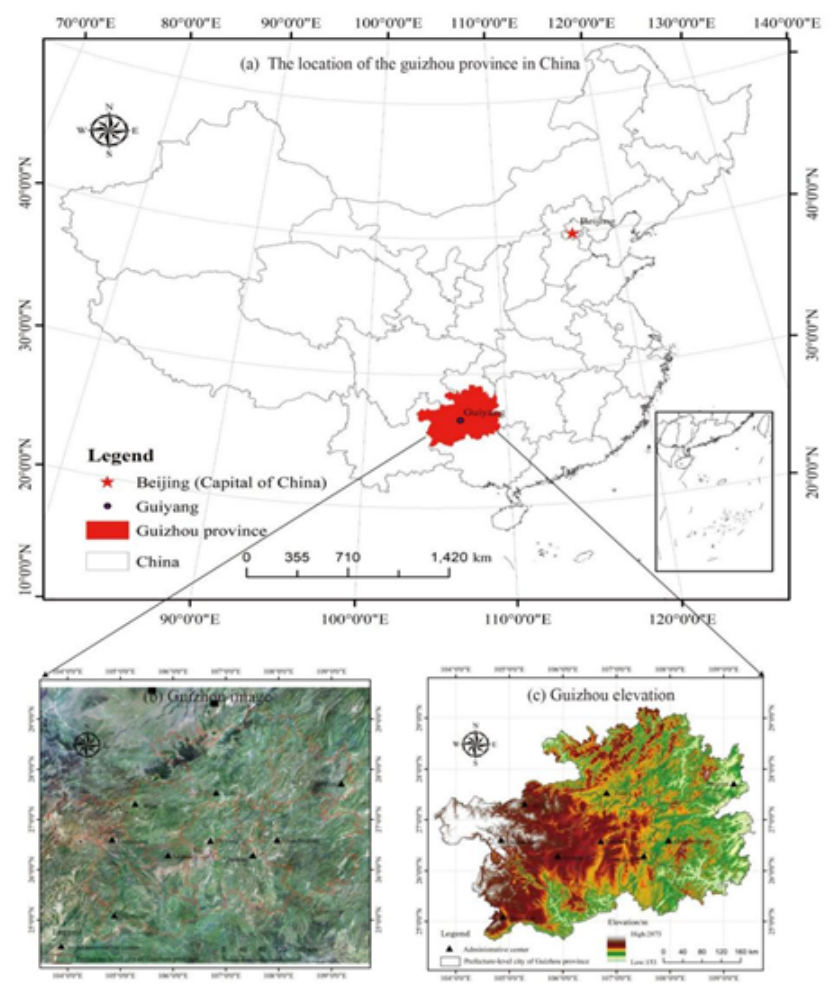

\section{Figure 2}

Location of the study area. 

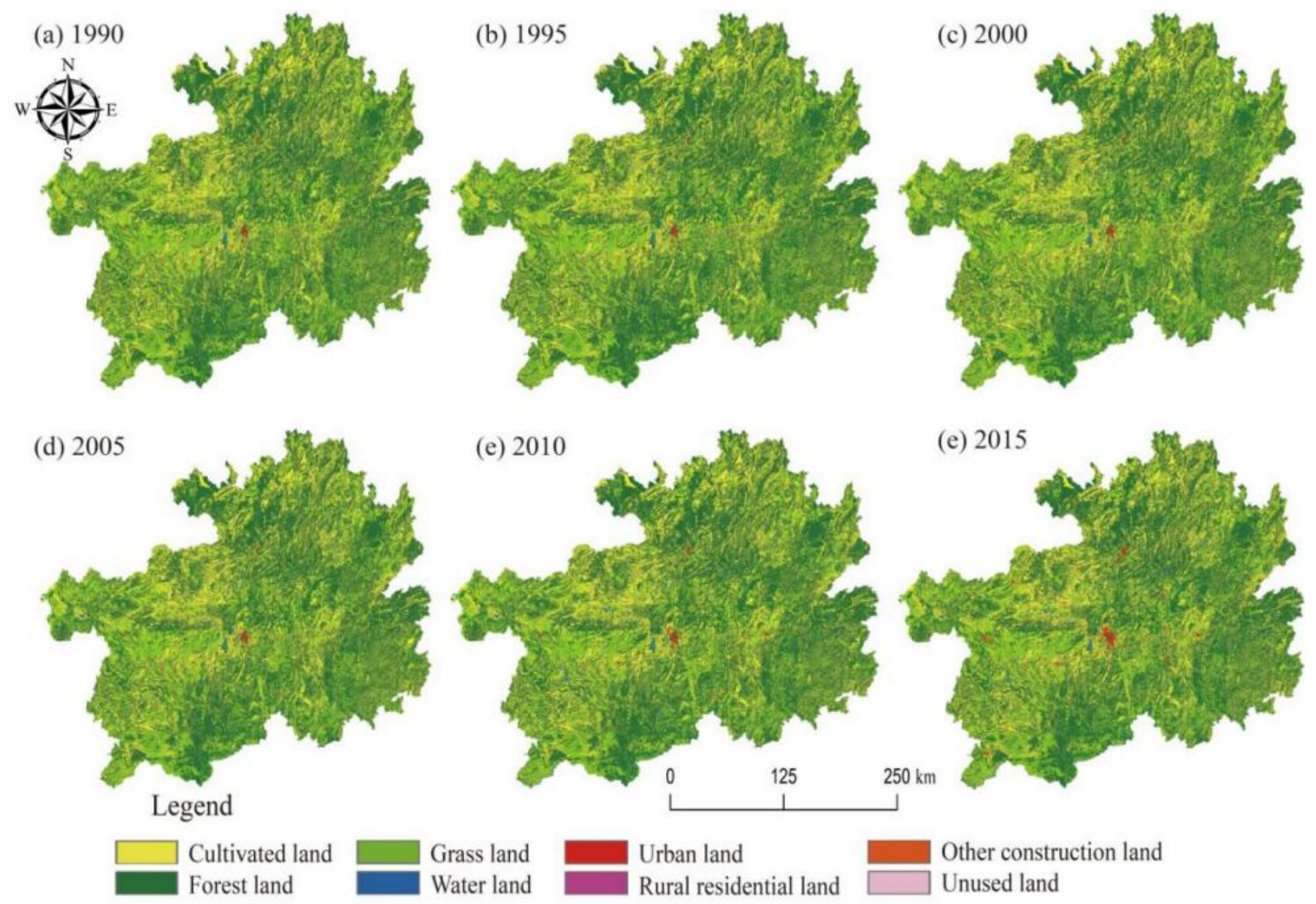

Grass land

Water land

Urban land

Rural residential land

Other construction land

Unused land

Figure 3

Land use map of Guizhou Province 

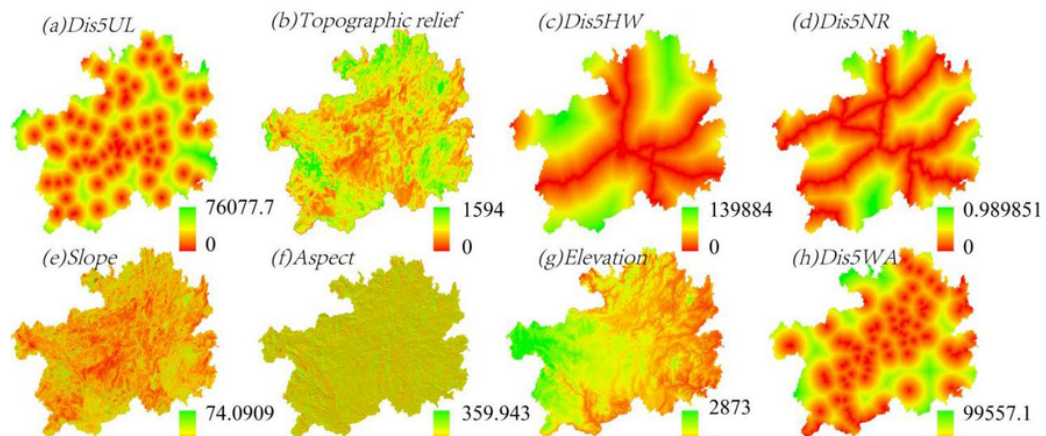

(g)Elevationt (h)Dis5WA 0
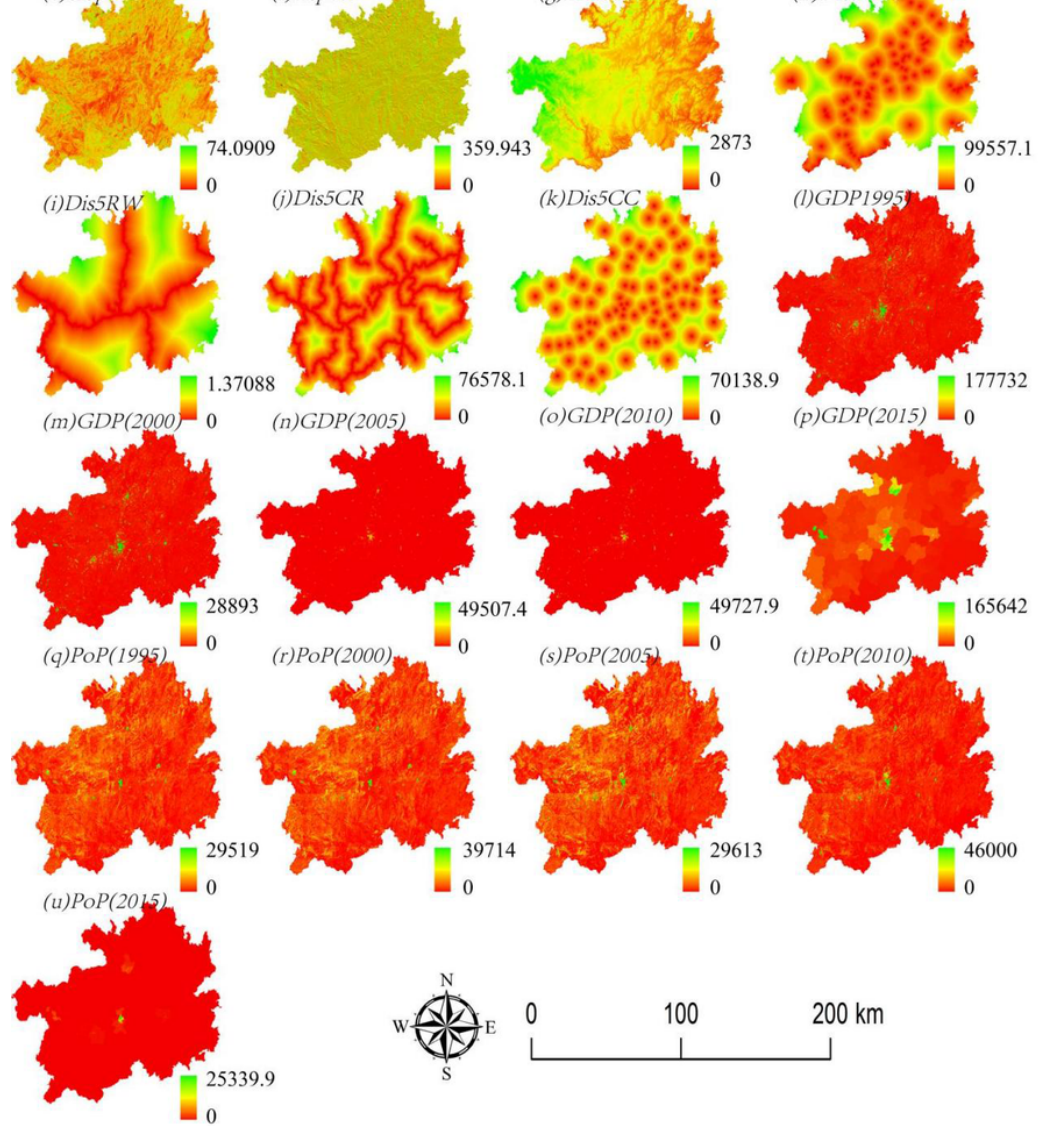

100

$200 \mathrm{~km}$

\section{Figure 4}

Visualization of each driving factor 


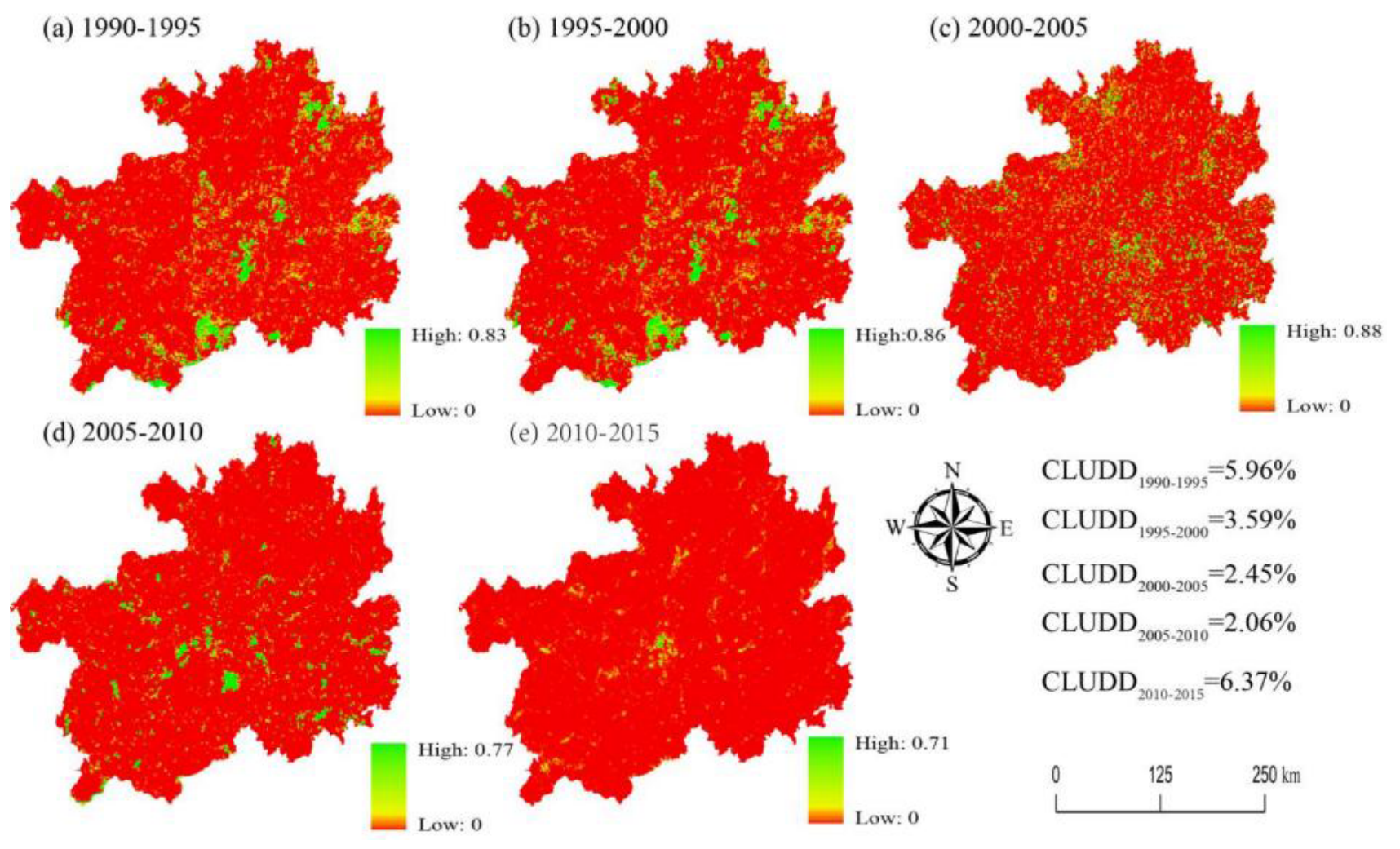

Figure 5

Spatial distribution of comprehensive land use in Guizhou Province

(a) 1990-1995

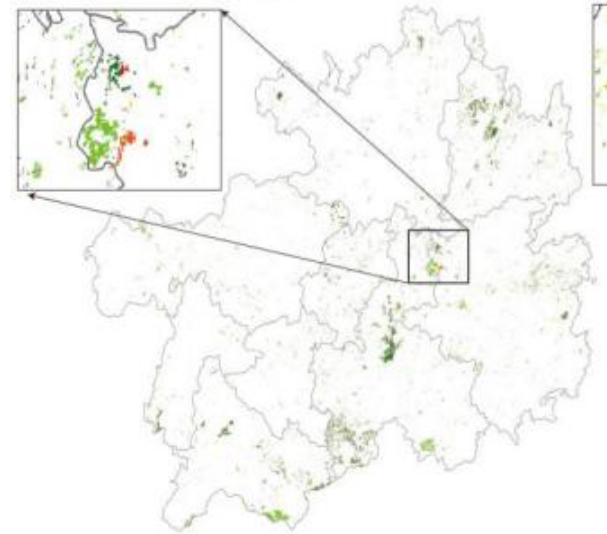

(d) $2005-2010$ (b) $1995-2000$

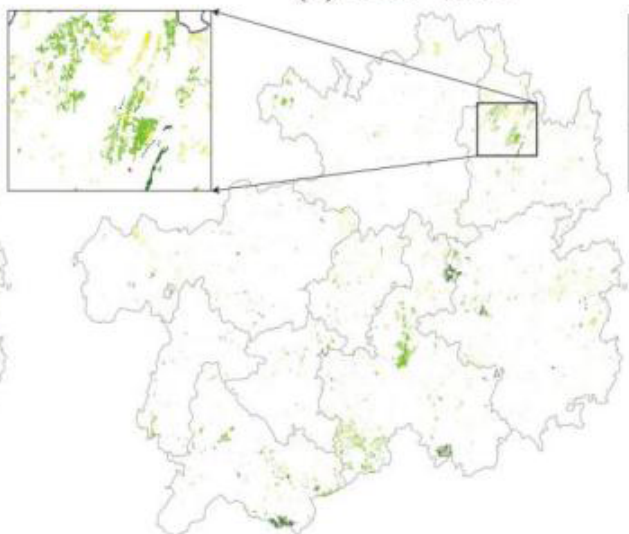

(e) 2010-2015
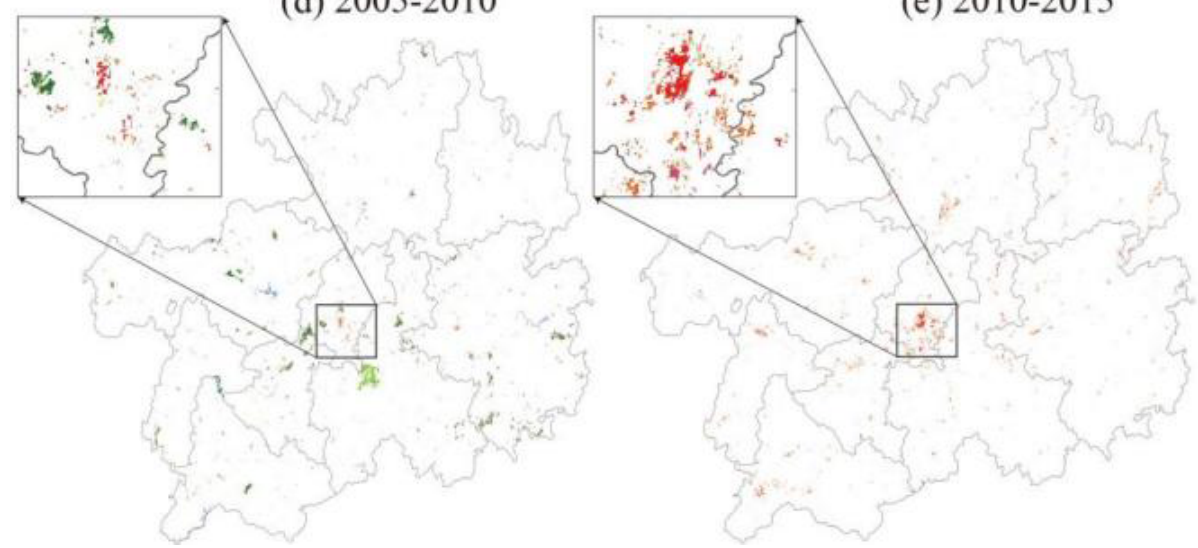

(c) $2000-2005$
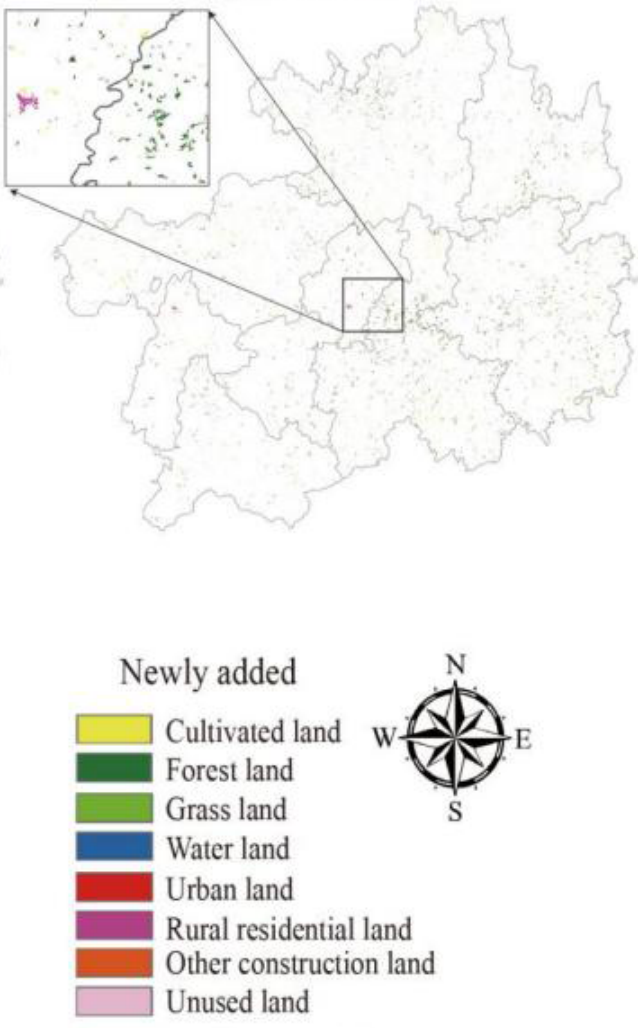

Figure 6 
land use growth atlas in Guizhou Province.

(a) 1990-1995

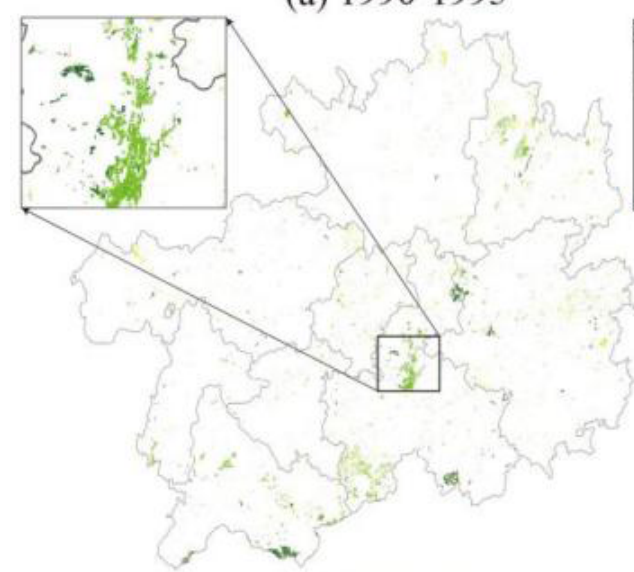

(d) $2005-2010$

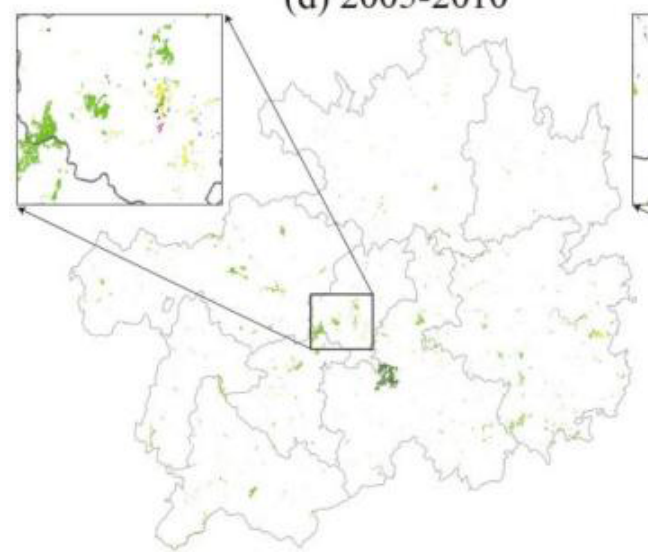

Figure 7

Land use shrinkage atlas in Guizhou Province. (b) $1995-2000$

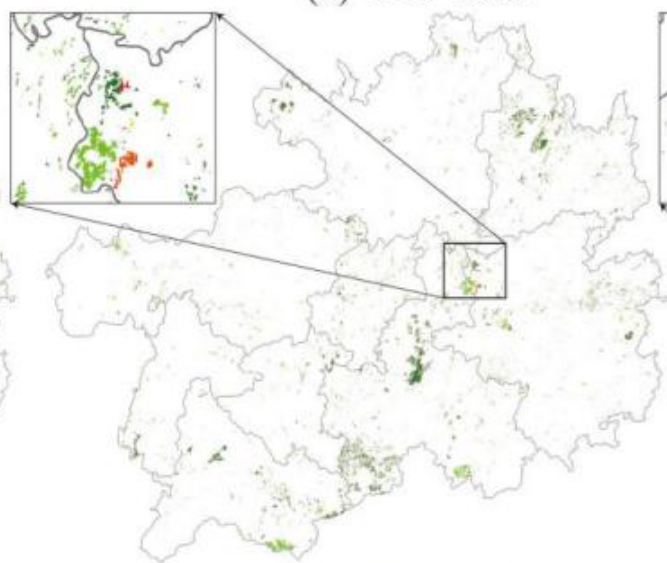

(e) $2010-2015$ (c) 2000-2005
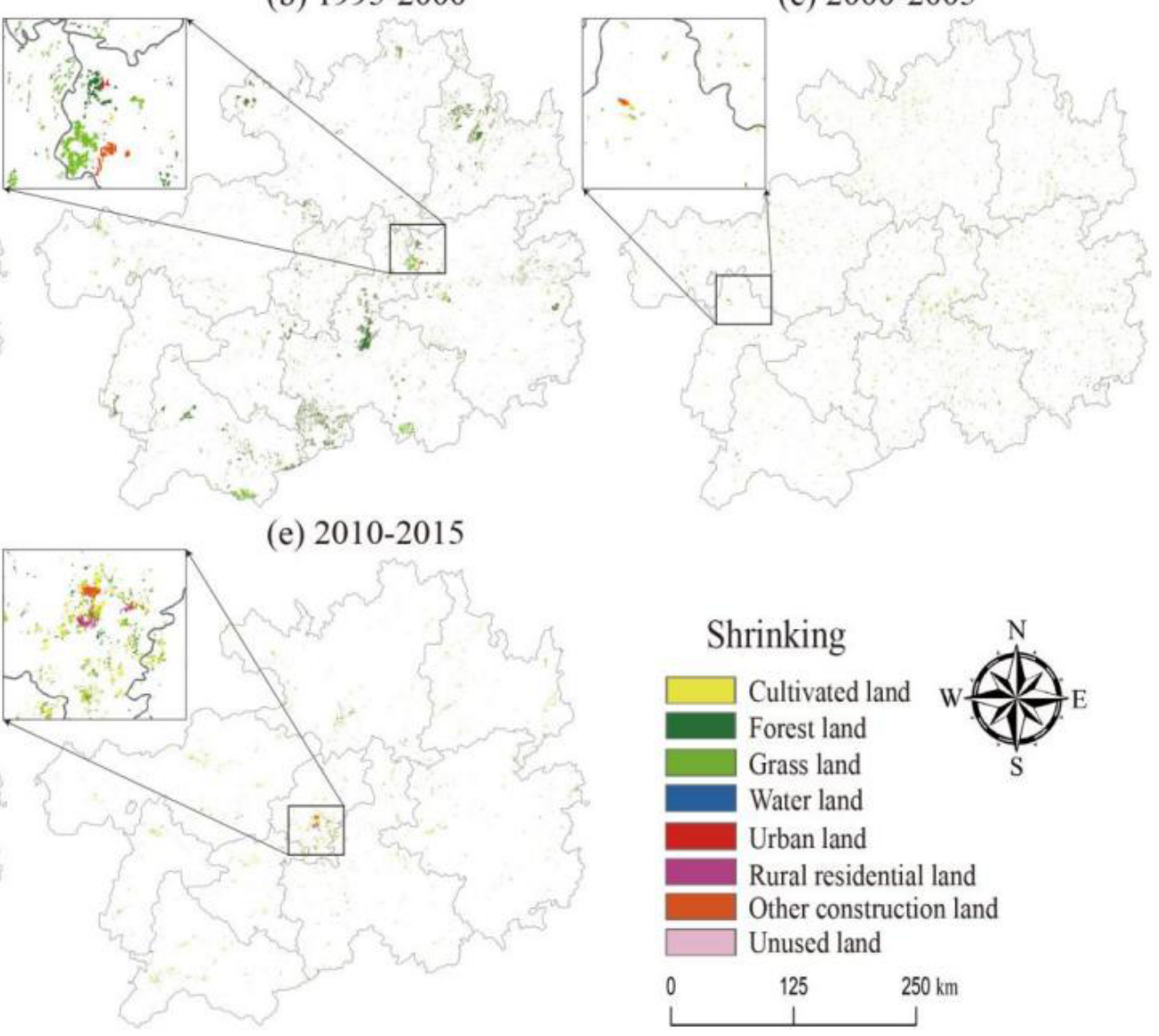
(a) Anshun

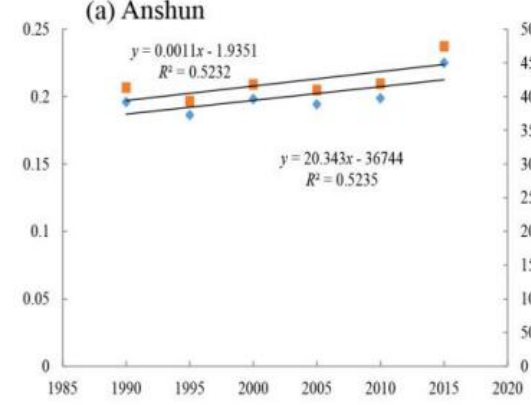

(d) Liupanshui

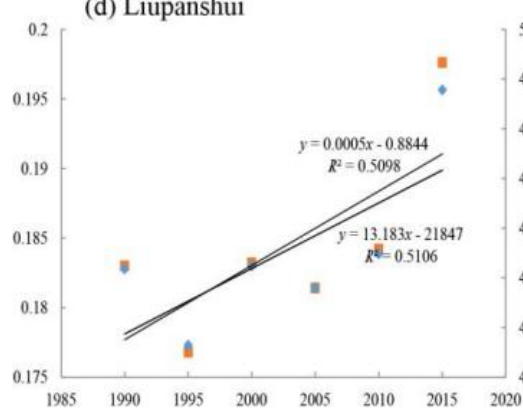

(g) Qianxinan

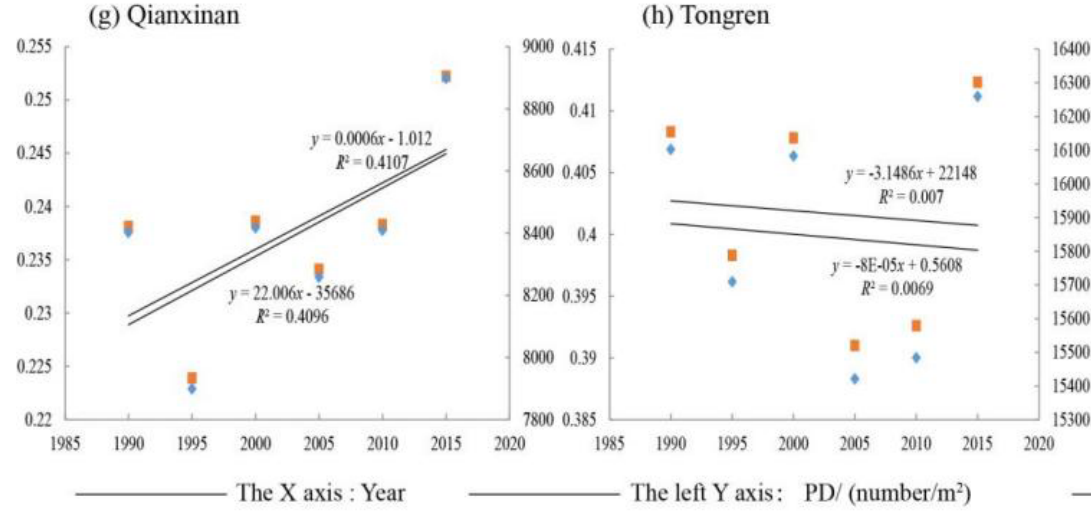

(c) Guiyang

(b) Bijie

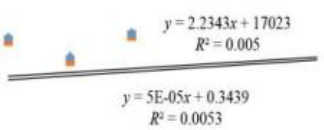

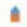

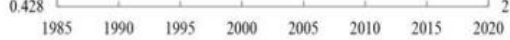

(e) Qiandongnan

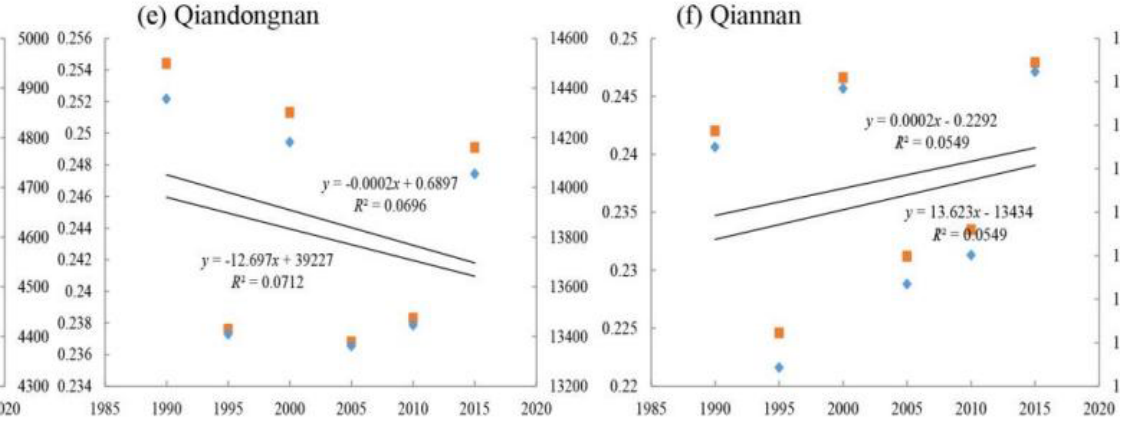

(i) Zunyi

Figure 8

The evolution characteristics of PD and NP in the prefecture-level cities of Guizhou Province. 
(a) Anshun

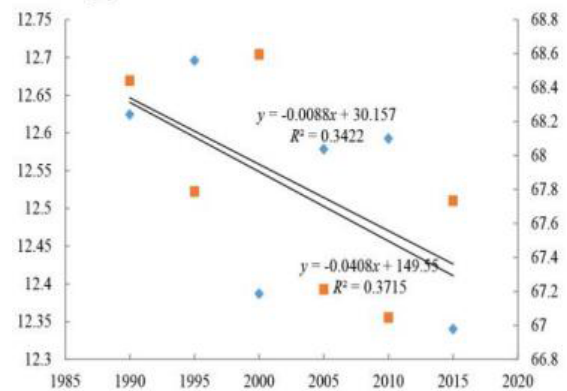

(d) Liupanshui

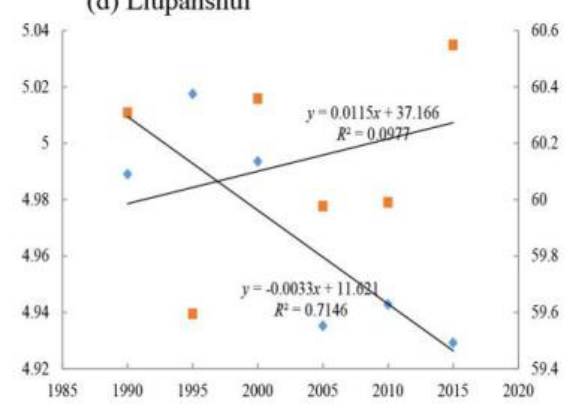

(g) Qianxinan

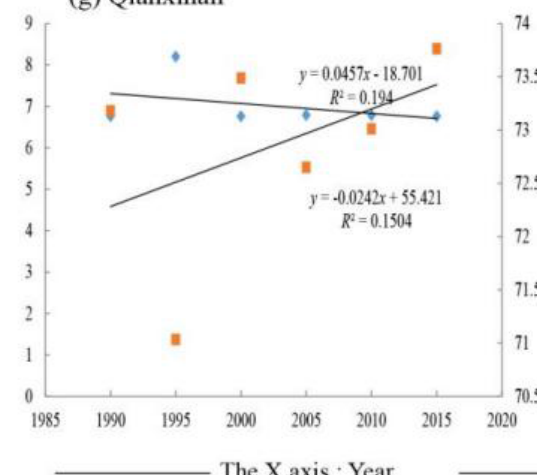

(b) Bijie

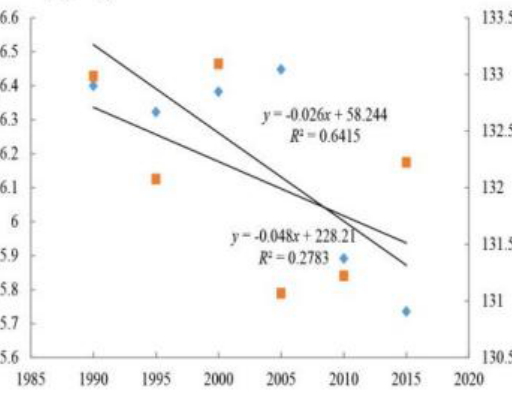

(e) Qiandongnan

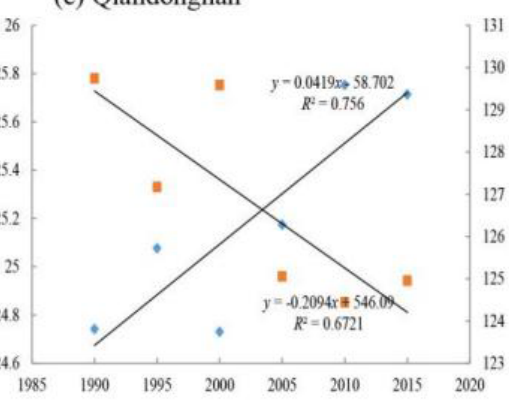

(h) Tongren

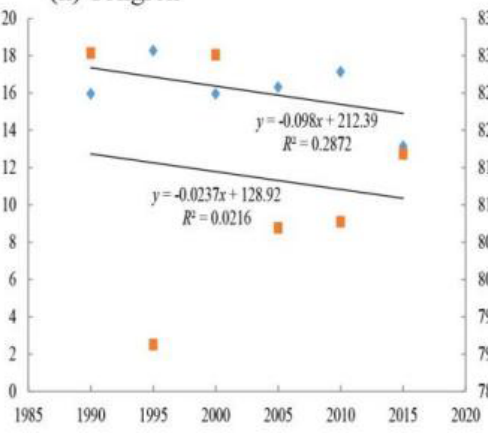

The left Y axis: LPI/ \% (c) Guiyang

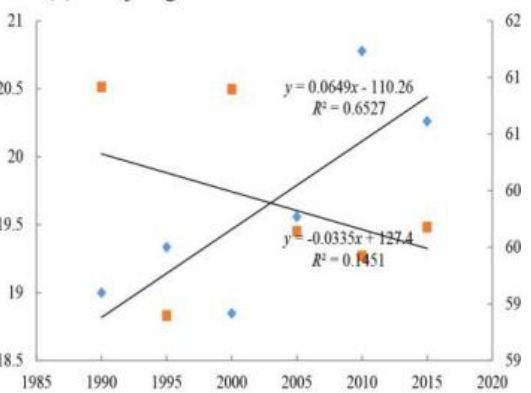

(f) Qiannan

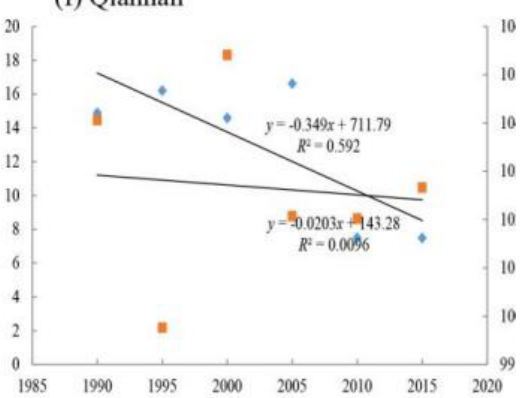

(i) Zunyi

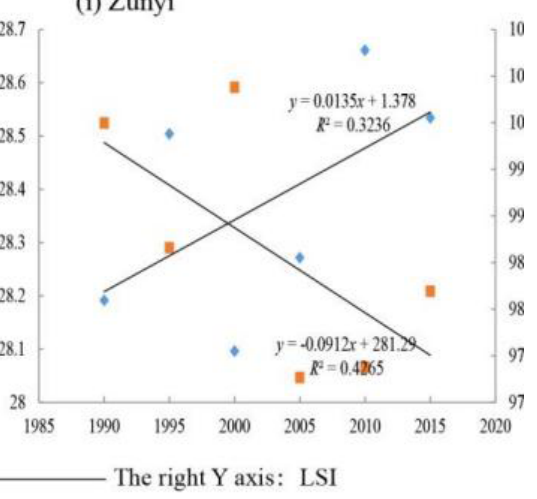

\section{Figure 9}

Evolution characteristics of LPI and LSI in prefecture-level cities of Guizhou Province. 

(a) 1990
(b) 1995
(c) 2000
(d) 2005
(e) 2010
(f) 2015
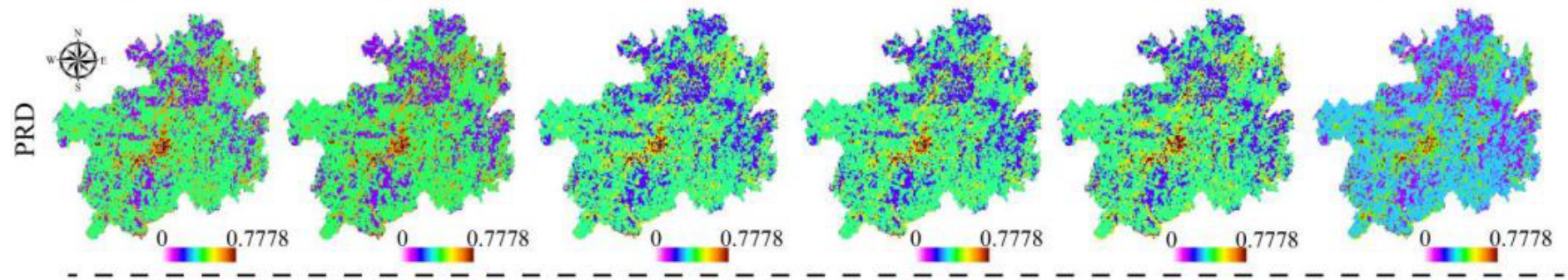

(g) 1990

(h) $\overline{1} 99 \overline{5}$

(i) 2000
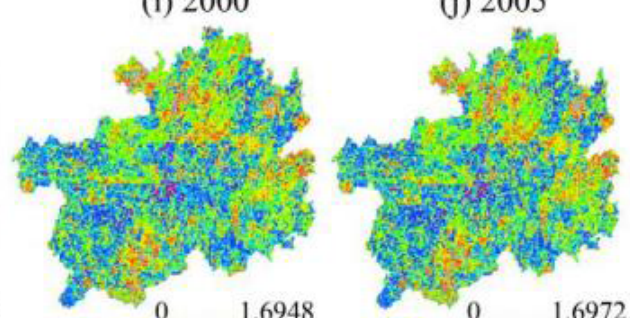

(k) 2010
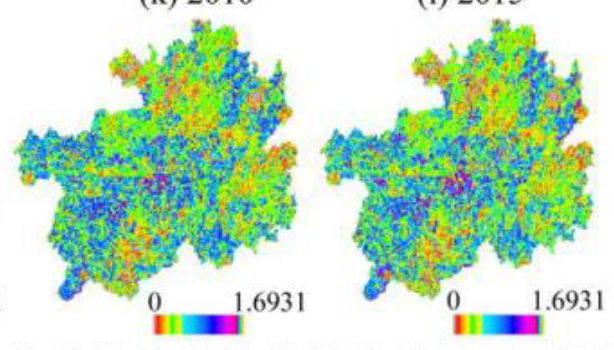

- - $-\overline{\text { m })} 1990$

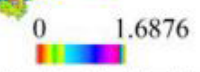

$\begin{array}{ll}0 & 1.6948\end{array}$

\begin{tabular}{l}
0 \\
IIIna \\
\hline
\end{tabular}

(o) 2000

(p) 2005

(q) 2010
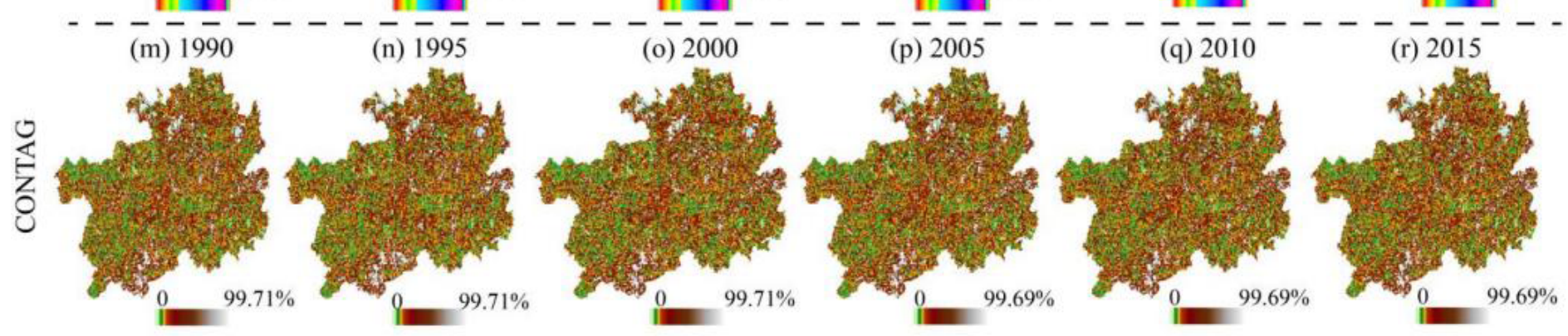

$0 \quad 125 \quad 250 \mathrm{~km}$

Figure 10

Spatial evolution characteristics of PRD, SHDI, and CONTAG in Guizhou Province. 


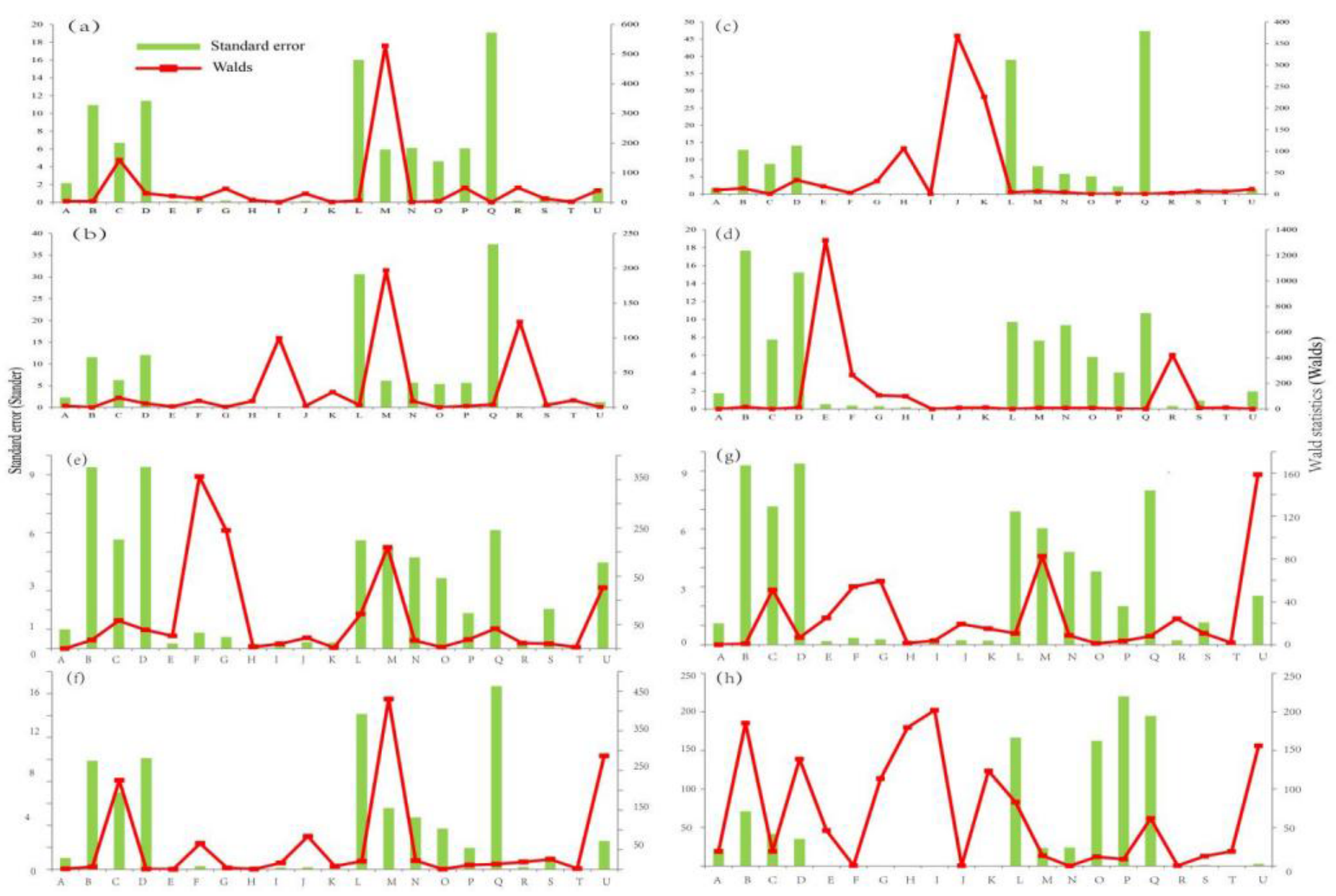

Figure 11

Statistical values of Walds and standard error of various land use types in Guizhou Province. (a)-Cultivated land, (b)-Forest land, (c)-Grassland, (d)-Water land, (e)-Urban land, (f)-Rural residential land, (g)-Other construction land, (h)-Unused land. A-GDP (2010), B-GDP (2015), C-POP (2010), D-POP (2015), EDis5WA, F-Dis5CC, G-DIS5UL, H-Dis5NR, I-Dis5HW, J-Dis5CR, K-Dis5RW, L-POP (1995), M-pop (2005), N-GDP (1995), O-GDP (2000), P-GDP(2005), Q-POP (2000), R-Elevation, S-Slope, T-Aspect, U-Topographic relief. 


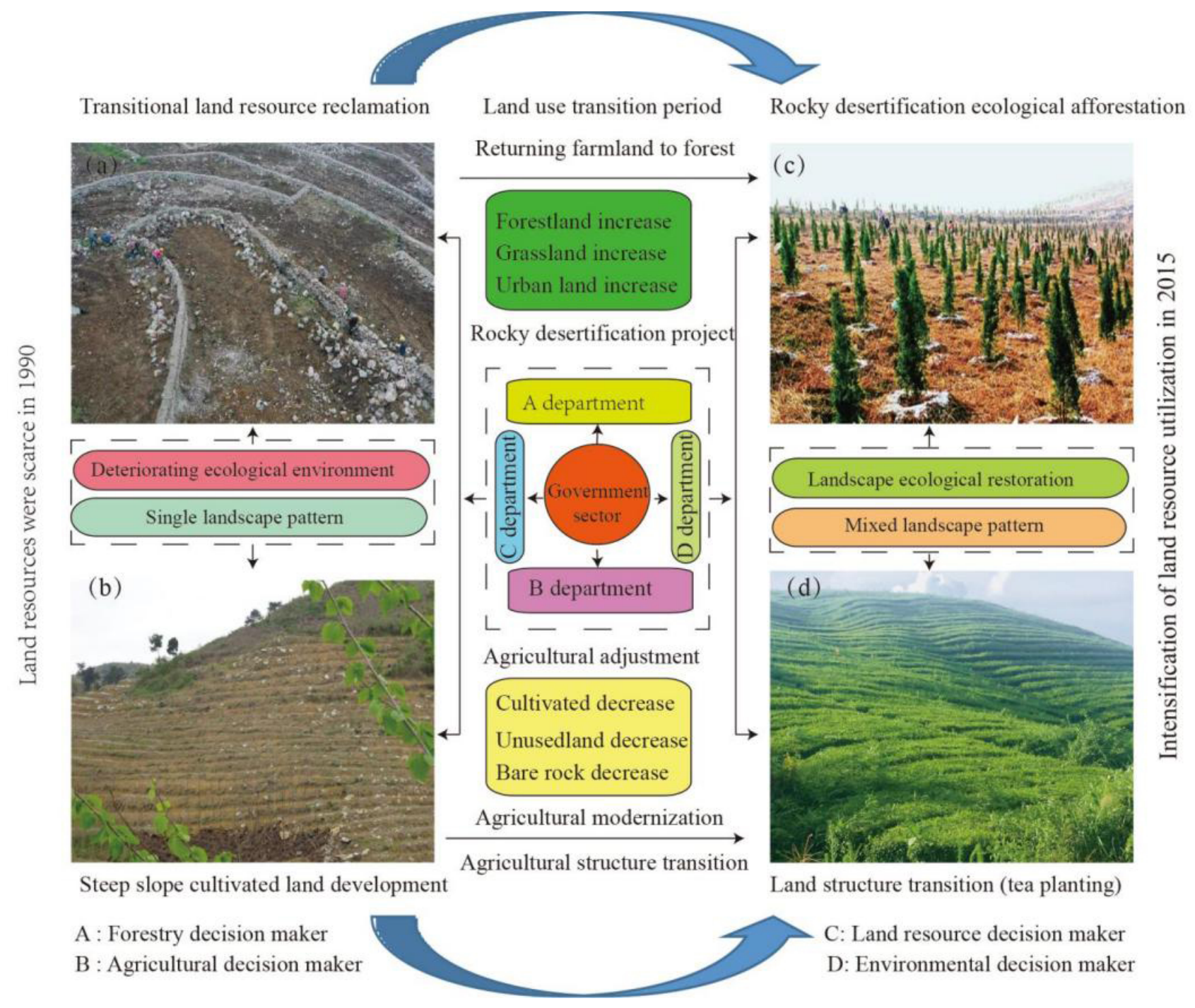

Figure 12

Ecological effects of land use transition and landscape pattern. 